\title{
Rehabilitation and renovation of cocoa (Theobroma cacao L.) agroforestry systems. A review
}

\author{
Eduardo Somarriba ${ }^{1}$ (1) - Felipe Peguero ${ }^{1} \cdot$ Rolando Cerda $^{1} \cdot$ Luis Orozco-Aguilar ${ }^{2} \cdot$ Arlene López-Sampson $^{1}$. \\ Mariela E. Leandro-Muñoz ${ }^{1} \cdot$ Patrick Jagoret $^{3,4} \cdot$ Fergus L. Sinclair $^{5}$
}

Accepted: 20 July 2021 / Published online: 16 September 2021

(c) The Author(s) 2021

\begin{abstract}
Cocoa farmers must decide on whether to rehabilitate $(\mathrm{Rh})$ or to renovate $(\mathrm{Re})$ a cocoa orchard when its productivity declines due to ageing, disease outbreaks or other causes. Deciding on $\mathrm{Rh} / \mathrm{Re}$ is often a complex, expensive and conflictive process. In this review, we (1) explore the diversity of contexts, driving forces, stakeholders and recommended management practices involved in $\mathrm{Rh} / \mathrm{Re}$ initiatives in key cocoa-producing countries; (2) summarise the often conflicting views of farmers and extension agents on $\mathrm{Rh} / \mathrm{Re}$ programmes; (3) review the evidence of age-related changes in planting density and yield of cocoa, given the weight of these variables in $\mathrm{Rh} / \mathrm{Re}$ decision processes; (4) describe the best known $\mathrm{Rh} / \mathrm{Re}$ systems and their most common management practices; (5) propose an agroforestry Re approach that overcomes the limitation of current Rh/ Re diagnosis protocols, which do not consider the regular flow of food crop and tree products, and the need to restore site soil quality to sustain another cycle of cultivation of cocoa at the same site; and (6) explore the effects of climate change considerations on $\mathrm{Rh} / \mathrm{Re}$ decision-making and implementation processes.

Each $\mathrm{Rh} / \mathrm{Re}$ decision-making process is unique and highly context-dependent (household and farm, soil, climate, culture). Tailored solutions are needed for each farmer and context. The analysis, concepts and models presented for cocoa in this paper may also apply to coffee orchards.
\end{abstract}

Keywords Site restoration · Climate change $\cdot$ Shade canopy $\cdot$ Early intercropping $\cdot$ Timber $\cdot$ Fruit $\cdot$ Natural mortality Coffee $\cdot$ Yield $\cdot$ Density

\section{Introduction}

Tree crops include a long list of commercially important species in both tropical (e.g. coffee, cocoa, oil palm, rubber, etc.) and temperate climates (e.g. olives, peaches, apples, etc.). Tree crops share two key features: (1) they are perennial plants with long life cycles and declining yields with age, and (2) they are expensive to establish and have long

Eduardo Somarriba

esomarri@catie.ac.cr

1 CATIE, Turrialba 30501, Costa Rica

2 Lutheran World Relief, PO Box 17061, Baltimore, MD 21297-1061, USA

3 CIRAD, UMR ABSys, F-34398, Montpellier, France

4 ESA/INP-HB, BP 1093, Yamoussoukro, Côte d'Ivoire

5 ICRAF, Research Program on Forests Trees and Agroforestry (FTA), United Nations Avenue, Nairobi, Kenya waiting periods (several years) before starting to reap benefits from the harvest of their products (e.g. pods, fruits, latex, etc.). Tree crops can be classified into two classes: (1) tall tree crops, such as rubber or oil palm, whether associated with other crops or not, that have their crowns in a dominant position in the vertical profile of the shade canopy. In this privileged position, they are the first ones to capture incoming solar radiation and cast shade on the other plant species in the understory, and (2) short tree crops such as cocoa (and coffee) that are usually cultivated under a shade canopy and consequently their growth and yield are partially dependent upon the nature and management of the taller plants that constitute the shade canopy. Irrespective of the class of tree crop, after several decades of cultivation, farmers must face the need to rehabilitate $(\mathrm{Rh})$, which involves restoring the productive capacity of a yet potentially productive orchard, or to renovate (Re), which involves removing all existing trees-at once or staggered over time-and planting new ones at the same site in the orchard (Fig. 1). 


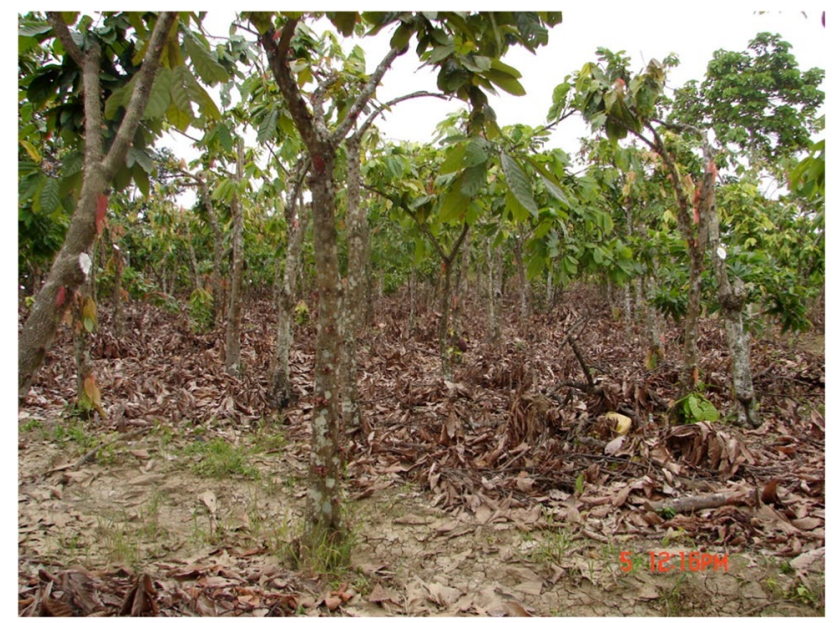

Fig. 1 Heavy pruning to reduce tree height and open the canopy of cocoa in coastal Ecuador (photograph by Eduardo Chavez, ESPOL, Guayaquil, Ecuador).

Rehabilitation and renovation $(\mathrm{Rh} / \mathrm{Re})$ of a cocoa orchard (either a no-shade monocrop or a shaded agroforestry system) is a complex decision-making process that involves diagnosis, design of innovations, and the formulation and implementation of an action plan. Cocoa agronomists have devised methods and protocols to help to decide when and how to Rh/Re an orchard (Fig. 2). Most methods are based on the assessment of whether three key variables have reached or passed critical threshold levels: (1) age of cacao (e.g. more than 40 years), (2) yields (e.g. less than $500 \mathrm{~kg} \mathrm{ha}^{-1}$ year $^{-1}$ ), and (3) planting density (e.g. less than 800 plants $\mathrm{ha}^{-1}$ ). Quiroz and Amores (2002) also consider pest and disease status, the height of the cocoa tree, and shade levels when deciding on $\mathrm{Rh} / \mathrm{Re}$ interventions. Critical levels for each variable are site and context specific and must be determined for each locality. For example, in the case of small Nigerian producers, an unproductive tree is the one whose yield is $25 \%$ of the average highest yield of an adult cocoa plant, i.e. about $125 \mathrm{~kg} \mathrm{ha}^{-1} \mathrm{year}^{-1}$ (Olaiya et al. 2006). The main limitation of these protocols is that only the age-yield-density relationships of cocoa are taken into consideration in the $\mathrm{Rh} / \mathrm{Re}$ decision-making and implementation process, disregarding the contributions and influence that the production of other agroforestry products from the same orchard (Cerda et al. 2014) have on $\mathrm{Rh} / \mathrm{Re}$ diagnosis, design and implementation.

In this review we (1) explore the diversity of contexts, driving forces, stakeholders and recommended management practices involved in $\mathrm{Rh} / \mathrm{Re}$ initiatives in key cocoa producing countries; (2) summarise the often conflicting views of farmers and extension agents on Rh/Re programmes; (3) review the evidence of age-related changes in planting density and yield of cocoa, given the weight of these variables in

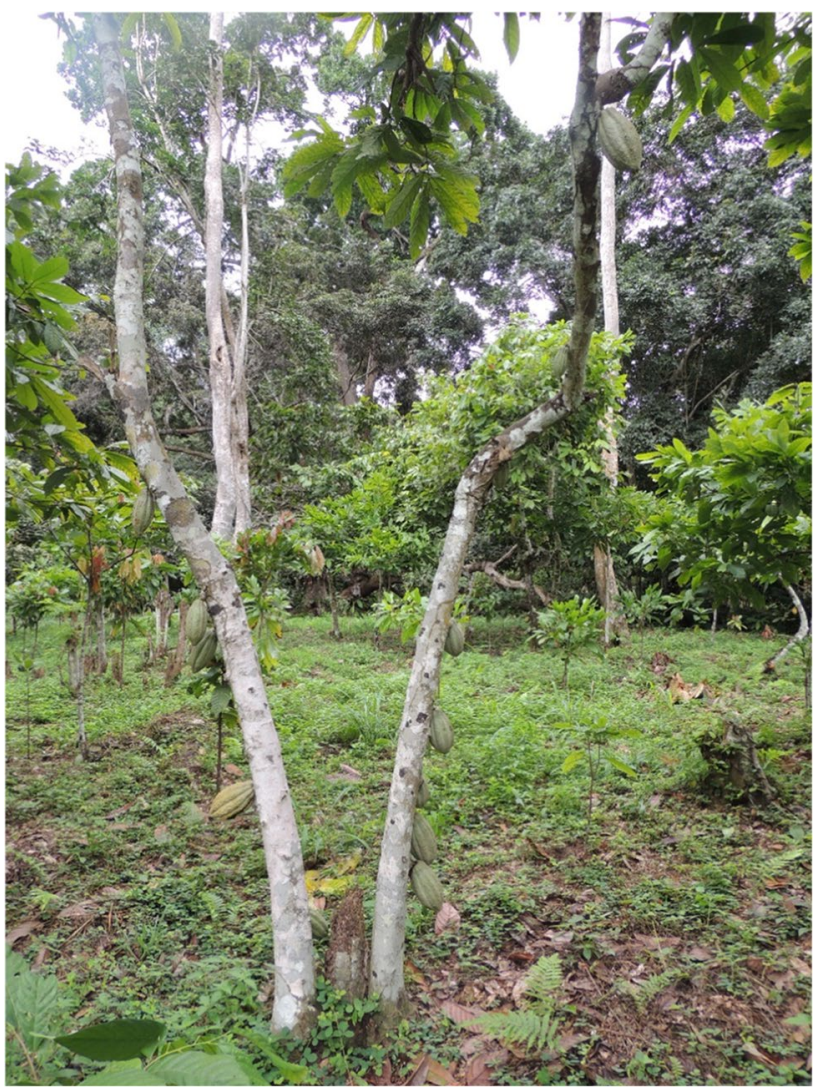

Fig. 2 Replanting an old cocoa agroforestry system, Obala, Cameroon (photograph by Patrick Jagoret).

$\mathrm{Rh} / \mathrm{Re}$ decision processes; (4) describe the best known $\mathrm{Rh} /$ Re systems and their most common management practices; (5) propose an agroforestry Re approach that overcomes the limitation of current $\mathrm{Rh} / \mathrm{Re}$ diagnosis protocols; and (6) explore the effects of climate change considerations on $\mathrm{Rh} /$ Re decision-making and implementation processes.

\section{$2 \mathrm{Rh} / \mathrm{Re}$ examples in cocoa-producing countries}

$\mathrm{Rh} / \mathrm{Re}$ decision-making and implementation processes are highly context specific. There are no general recipes, so each process needs tailored solutions, as exemplified by $\mathrm{Rh} / \mathrm{Re}$ initiatives in the Dominican Republic, Ecuador, Peru, Brazil, Cote d'Ivoire, Ghana and Indonesia.

- Dominican Republic. Recurrent hurricanes and the availability of new technologies to increase crop yield (improved genetics, new grafting techniques, etc.) have been the two major driving forces in $\mathrm{Rh} / \mathrm{Re}$ initiatives in the Dominican Republic. Government, private companies and major farmers' organisations have engaged

\section{Springer INRAC}


in $\mathrm{Rh} / \mathrm{Re}$ initiatives. For example, in the late 1960s, a government-led $\mathrm{Rh} / \mathrm{Re}$ programme introduced selected, high-yielding clones from Trinidad, Ecuador, Jamaica and Costa Rica (Batista 2009). In 2006, the government promoted side grafting to rehabilitate old and unproductive cocoa trees in pioneer cocoa fronts (Siegel and Alwang 2004), and in 2017 launched a 10-year National Action Plan in partnership with the UNDP's Green Commodities Program (Cuello et al. 2015). CONACADO, an emblematic, small farmers' organisation, in partnership with Equal Exchange (an NGO), and with funding from USAID, is currently engaged in $\mathrm{Rh} / \mathrm{Re}$ their organically grown cocoa orchards (https://equalexchange.coop/ sites/default/files/INFORMEParcelasDemostrativasCO NACADO2018.pdf).

- Ecuador. Most Rh/Re interventions have been part of a government-backed programme with local financial institutions as lenders (Quiroz and Amores 2002). The Ministry of Agriculture claimed to have rehabilitated or renovated more than 100,000 ha of low-yielding cocoa plantations heavily affected by pest and diseases or reaching the end of their life expectancy over a 10-year period (2006-2015) (https://www.agricultura.gob.ec/productivi dad-rendimientos-cacao/).

- Peru. Rh/Re initiatives have been linked to USAID's financial and logistic support to both eradicate coca plantations (Erythroxylon coca) and to promote cocoa as a licit, alternative crop to sustain rural livelihoods (Kieck et al. 2016; Scott et al. 2015), for instance, the Peru Cacao Alliance (Alianza Cacao Perú) programme, USAID's 10-year programme in the Provinces of San Martin, Ucayali and Huanuco (http://www.alianzacac aoperu.org/).

- Brazil. The devastating outbreak of Witches' Broom (Moniliophthora perniciosa) in the late 1980s (Teixeira et al. 2015; Poelmans and Swinnen 2016) triggered several $\mathrm{Rh} / \mathrm{Re}$ initiatives aimed at restoring yields and production, and the promotion of a set of good management practices, including the replacement of the traditional, susceptible cocoa genotypes by new, disease- and drought-resistant, high-yielding, and fine flavour cocoa cultivars, combined with integrated pest management practices, agroforestry and low carbon cultivation practices (Pekic 2014; van der Kooij 2013; Schroth et al. 2016a).

- Cote d'Ivoire and Ghana. Pest and disease outbreaks (e.g. cocoa swollen shoot virus, CSSV) have been a major driving force in $\mathrm{Rh} / \mathrm{Re}$ decisions in the two major global cocoa producers (Ameyaw et al. 2014; Andres et al. 2017). In Côte d'Ivoire, the Quantity-Quality-Growth (2QG) programme (2014-2023) was set up by the Ministry of Agriculture and Rural Development (MINADER) and the Conseil Café-Cacao (CCC) to rehabilitate and renovate 800,000 ha of degraded cocoa plantations, including 150,000 ha destroyed by the CSSV. Recommended practices include the introduction of new cocoa varieties (high-yielding, drought-resistant, good-quality chocolate), maintenance pruning, fertiliser application, regeneration by grafting and crop protection measures (Dzahini-Obiatey et al. 2010; Andres et al. 2018). The CSSV outbreak was also the driving factor that led to the Government of Ghana and the World Bank to invest USD 100 million to rehabilitate and renovate 17,900 ha of CSSV-infected cocoa farms (Kwaw-Nimeson and Tian 2019). Rehabilitation and renovation is recommended in current projects under Cote d'Ivoire and Ghana's Cocoa and Forestry Initiative (CFI), in partnership with the major cocoa and chocolate companies (represented by the World Cocoa Foundation), international NGOs (IDH, in this case), and other stakeholders. The CFI simultaneously targets increasing incomes from increased cocoa yields, preventing deforestation, and promoting the cultivation of cocoa in agroforestry systems to diversify and sustain rural incomes and to restore previously deforested land (Kroeger et al. 2017; Schroth et al. 2015a). Renovation of cocoa orchards poses a risk to deforestation, given the preference of farmers to establish new cocoa orchards in forest areas to take advantage of high soil fertility (Clough et al. 2009; Vaast and Somarriba 2014; Somarriba and López-Sampson 2018).

- Large-scale $\mathrm{Rh} / \mathrm{Re}$ programmes have been implemented across West Africa (Ivory Coast, Cameroon and Ghana) in two main waves (1970 and 1990) but with low success rate due to farmers' lack of financial resources to entirely implement such interventions (Longworth 1963; Are 1970b; Lockwood 1976). Such programmes have typically integrated research and extension services to transfer improved planting materials and dissemination of best agronomic practices. The financing of such programmes has been heavily or entirely subsidised (Jagoret et al. 2011; Dalberg 2015). Currently, the cocoa private sector is supporting several $\mathrm{Rh} / \mathrm{Re}$ programmes to improve yields and secure a steady supply of cocoa beans (https://www.worldcocoafoundation.org/initiative/ african-cocoa-initiative-ii/). These programmes are being implemented on over 1.2 million ha of cocoa orchards and focus on two areas: (1) providing a $\mathrm{Rh} / \mathrm{Re}$ package including inputs, high-quality planting material (high yield, disease and drought resistant, good chocolate quality) and high-quality agronomical training and (2) setting up a business-driven provision of extension services.

- Indonesia. Aging plantations, low yields and disease incidence triggered $\mathrm{Rh} / \mathrm{Re}$ interventions on more than 0.8 million ha of cocoa orchards. Between 2000 and 2010, the Government of Indonesia became heavily involved in $\mathrm{Rh} / \mathrm{Re}$ programmes by providing loans and subsi- 
dised inputs. Since 2010 onwards, private companies, several development agencies and other public-private partnerships have been implementing ambitious $\mathrm{Rh} / \mathrm{Re}$ programmes to build up and complement former efforts (Lockwood and Yin 1996; Thau Yin 2004). The overall goal of these $\mathrm{Rh} / \mathrm{Re}$ interventions is to increase yields from the current average of $400-450 \mathrm{~kg} \mathrm{ha}^{-1}$ to $1.5 \mathrm{Mt}$ $\mathrm{ha}^{-1}$ to outcompete alternative cash crops such as palm oil.

\section{To $R h / R e$ or not to $R h / R e$ ? Extension agents versus farmers}

At least five major factors have been found to drive cocoa farmers into $\mathrm{Rh} / \mathrm{Re}$. First is the fall in cocoa yields due to the combined effect of plant ageing, the reduction in cocoa population density (linked to accumulated natural mortality), and increased incidence of pests and diseases (Aikpokpodion and Adeogun 2011; Jagoret et al. 2011; Mahrizal et al. 2014; Wessel and Quist-Wessel 2015; Adebiyi and Okunla 2013; Akinnagbe 2015; Dias et al. 2000; Adeogun et al. 2010). Second is the need to restore the productive capacity of a cocoa orchard that is still productive after a period of abandonment that may be due to the prolonged falling of cacao prices, the invasion of pests and diseases (DzahiniObiatey et al. 2006; Quiroz and Amores 2002; Are 1969b, 1970a; Danquah 2003; Laryea 1969; Longworth 1963; Tresh and Lister 1960), wars and other social-political causes (Krauss and Soberanis 2002; Ofori-Bah and Asafu-Adjaye 2011; Assiri et al. 2003; Laryea 1969), and difficulties in the transmission of hereditary rights over the orchard (Jagoret et al. 2018). Third is farmers' expectations of good cocoa prices (or access to incentives) for a sufficient length of time (Akinnagbe 2015; Trivedi 1988) that prompt them to replace their old, low-yielding orchard with a new, high-yielding one (Trivedi 1988). Fourth is incentives and subsidies, including technical, financial and operational support, as well as other incentives (Adebiyi and Okunla 2013; Akinnagbe 2015, 2017; Aneani et al. 2017; Asare et al. 2018; Dalberg 2015; Laryea 1969; Murray and Jones 1969; Obiri et al. 2007; Wessel and Quist-Wessel 2015). Fifth is social processes linked to migration and labour availability. For example, in Ghana, when the main family labour force of a household (the sons and daughters) have emigrated, their parents turn to sharecropping their land with young immigrants who are interested in high and rapid returns and usually choose to renovate the old, traditional cocoa orchards (Amelonado variety, mixed shade canopy, no use of agrochemicals, low yields) and replace it with hybrid cocoa, in full sun, and using agrochemicals to achieve higher yields (Ruf 2011; Ruf and Zadi 1998).
Rehabilitation or renovation of a cocoa orchard is a risky and costly task (Akinnagbe 2015; Dalberg 2015), so it is no wonder that farmers are usually reluctant to engage in Rh/Re (Aneani and Padi 2016; Lass 1985). Farmers' most common reasons for not rehabilitating or renovating their orchard include the following:

- There is a significant loss of earnings for several years before the new orchard starts production (Riedel et al. 2019; Laryea 1969).

- High investments must be made in the removal of the old orchard and the establishment and management of the new one (Asare et al. 2018).

- Distrust of the (yet unknown) performance of new technology, especially under a changing climate (Akinnagbe 2015).

- Family, cultural or personal values that outweigh the value of economic losses from cocoa. For example, indigenous cocoa farmers in Talamanca, Costa Rica will not cut down the old cocoa orchard planted by their grandfather 60 years ago, even if it does not produce any cocoa and it is a source of inoculum and disease affecting the rest of the farm (E. Somarriba, personal observations).

- Farmers and agronomists differ in their definition of 'acceptable yields' (Danquah 2003). For example, a cocoa orchard 30-35 years old may still be considered productive by a farmer because the production cost involved is essentially the cost of harvesting, and as long as the yield covers this minimum cost and generates some surplus they will keep the orchard as it is (Laryea 1969; Olaiya et al. 2006; Upton 1966). Farmers believe that extension agents do not understand their household and cocoa farming reality (Andres et al. 2017).

Quite often the reluctance of farmers to $\mathrm{Rh} / \mathrm{Re}$ is overridden by incentives and subsidies. There is a rich literature on the adoption, micro-economics and politics involved in $\mathrm{Rh} /$ Re programmes (see Adeogun et al. 2010; Ogunniyi and Osuolale 2015; Gotsch and Burger 2001; Obiri et al. 2007; Trivedi 1988; Adebiyi and Okunla 2013).

\section{Cocoa age-yield-density relationships}

Understanding the relationships between yield, density and age is central to $\mathrm{Rh} / \mathrm{Re}$ diagnosis and design. Cocoa agronomists base their $\mathrm{Rh} / \mathrm{Re}$ diagnosis and design protocols on combinations of these three variables (Olaiya et al. 2006; Quiroz and Amores 2002; Vaz 1995; Matlick et al. 1999). Three questions must be answered to understand these relationships: (1) how does yield per hectare change with density? (2) Given an initial planting density, how will density 
change with age? (3) How does yield per plant change with age? These questions are addressed below.

Cocoa yield per hectare $(Y)$ has two components: the population density of cocoa trees (for brevity, 'density', $n=$ plants $^{-1}$ ) and the yield (of dry cocoa beans) per plant $(y)$. Both components vary with age $(t)$ (Eq. 1):

$Y_{t}=y_{t} * n_{t}$

where

$y_{t}=f_{1}(t)$

and

$n_{t}=f_{2}(t)$

and $f_{1}$ and $f_{2}$ are two unknown functions.

\subsection{How does yield per hectare change with density?}

Determining the optimal planting density to achieve maximum yield per hectare $(Y)$ and finding the most appropriate mathematical expression for this relationship have been central research topics in ecology, forestry, agronomy and agroecology (Bleasdale and Nelder 1960; Mead 1970; Panik 2013; Vandermeer 1984; Willey and Heath 1969; Yahuza 2011). These studies typically show that at low density, individual plants do not compete with their neighbours, yield per plant $(y)$ is at its maximum, unencumbered yield, and $Y$ increases linearly when density increases until competition sets in, depressing yield per plant. Crop species are classified as depicting 'asymptotic' or 'parabolic' patterns (Yahuza 2011; Panik 2013). Optimal density is usually determined when the curves of yield per hectare $(Y)$ and yield per plant (y) intersect (Fig. 3).

Remarkably few studies have explored the relationship between cocoa yield and planting density. The scarce experimental evidence indicates that cocoa yield per hectare increases with planting density (Armstrong 1976; Charles 1961; Dias et al. 2000; Pacheco et al. 2003; Kowal 1959; Smith 2015; Spaggiari Souza et al. 2009; Mooleedhar and Lauckner 1990). Lockwood and Yin (1996) found no differences in yields in the density range evaluated. In Trinidad, Mooleedhar and Lauckner (1990) observed increasing yield per hectare when cocoa density in young cocoa orchards increased from 748 to 2990 cocoa trees $\mathrm{ha}^{-1}$. An experiment in Ghana testing yields in orchards planted at densities between 474 and 6726 trees ha ${ }^{-1}$ showed that the optimal density for yield performance per hectare was 1977 trees (Alvim 1964; Smith 2015). At densities above 4448 trees $\mathrm{ha}^{-1}$, competition suppressed many trees and depressed fruit production in residual trees (Wood 1964). In Central Cameroon, Jagoret et al. (2017a) showed that the highest cocoa yields (more than $1 \mathrm{Mg} \mathrm{ha}^{-1}$ ) were obtained with 1568 cocoa trees $\mathrm{ha}^{-1}$. In these cocoa farms, yield decreased as the density of cocoa trees increased, but it also appeared to be highly dependent on the density of the associated trees, which was of 155 trees ha ${ }^{-1}$ in the most productive cocoa farms. In Bahia, Brazil, higher yields were obtained at higher densities in the range of 1000-5000 trees ha ${ }^{-1}$. However, using the maximum cocoa planting density is not always possible because it also increases the incidence of diseases (Dias et al. 2000; Spaggiari Souza et al. 2009).

\subsection{Plantation and farmer cocoa production models}

Typical cocoa planting densities differ between cocoa geographies. Historical reasons explain observed patterns. There are two basic cocoa production models: (1) low planting density in the 'Plantation Model' and (2) high planting density in the 'Farmer Model' (Urquhart 1961; Vernon 1971). The Plantation Model was developed in the Antilles and spread to Sri Lanka, Southeast Asia, the Pacific Islands and other localities during the Spanish colonial era (fifteenth to eighteenth centuries). It was the only cacao production model until the nineteenth century. This model uses nursery seedlings and planting density between 400 and 1200 plants ha ${ }^{-1}$ (Urquhart 1961; Freeman 1929), regular pruning to control plant size and shape, regular and frequent removal of suckers, and planted shade. For instance, in the Plantation Model in Brazil, cacao was planted at 600-700 trees ha ${ }^{-1}$ until the beginning of the twentieth century, but then planting density was increased to 1111 plants $^{-1}(3 \times 3 \mathrm{~m})$, a system that is still in use today. In agroforestry models in Brazil, cacao plantation density does not exceed 400 trees $\mathrm{ha}^{-1}$ (Spaggiari Souza et al. 2009). Cocoa plantations in Central America (Panama, Costa Rica, Nicaragua, Honduras, Guatemala, Belize) have an average of 625 (ranging between 450 and 800) plants ha ${ }^{-1}$. New plantings in Central America are established at 1100 plants $^{-1} \mathrm{a}^{-1}$ at a recommended spacing of $3 \times 3 \mathrm{~m}$ (Orozco-Aguilar et al. 2015).

The Farmer Model is typical of Africa. In its origins in the nineteenth century, cocoa was planted under heavily thinned primary forests or under old secondary forests through the direct sowing of closely spaced cocoa planting sites and 2-4 seeds per planting site to compensate for expected substantial mortality losses at the establishment of the orchard (Lass 1985). Planting sites were not rigorously demarcated due to the presence of big roots and trunks of the shade canopy trees; cocoa planting density varied between 3,141 and 10,000 trees ha ${ }^{-1}$ (Vernon and Morris 2015). Nowadays, farmers in Ghana prefer planting cocoa trees without lining and pegging to reduce labour costs, typically planting at close spacing and reducing density by thinning after natural mortality during establishment has taken its toll (Asare et al. 2018). In Cameroon, the average density is 


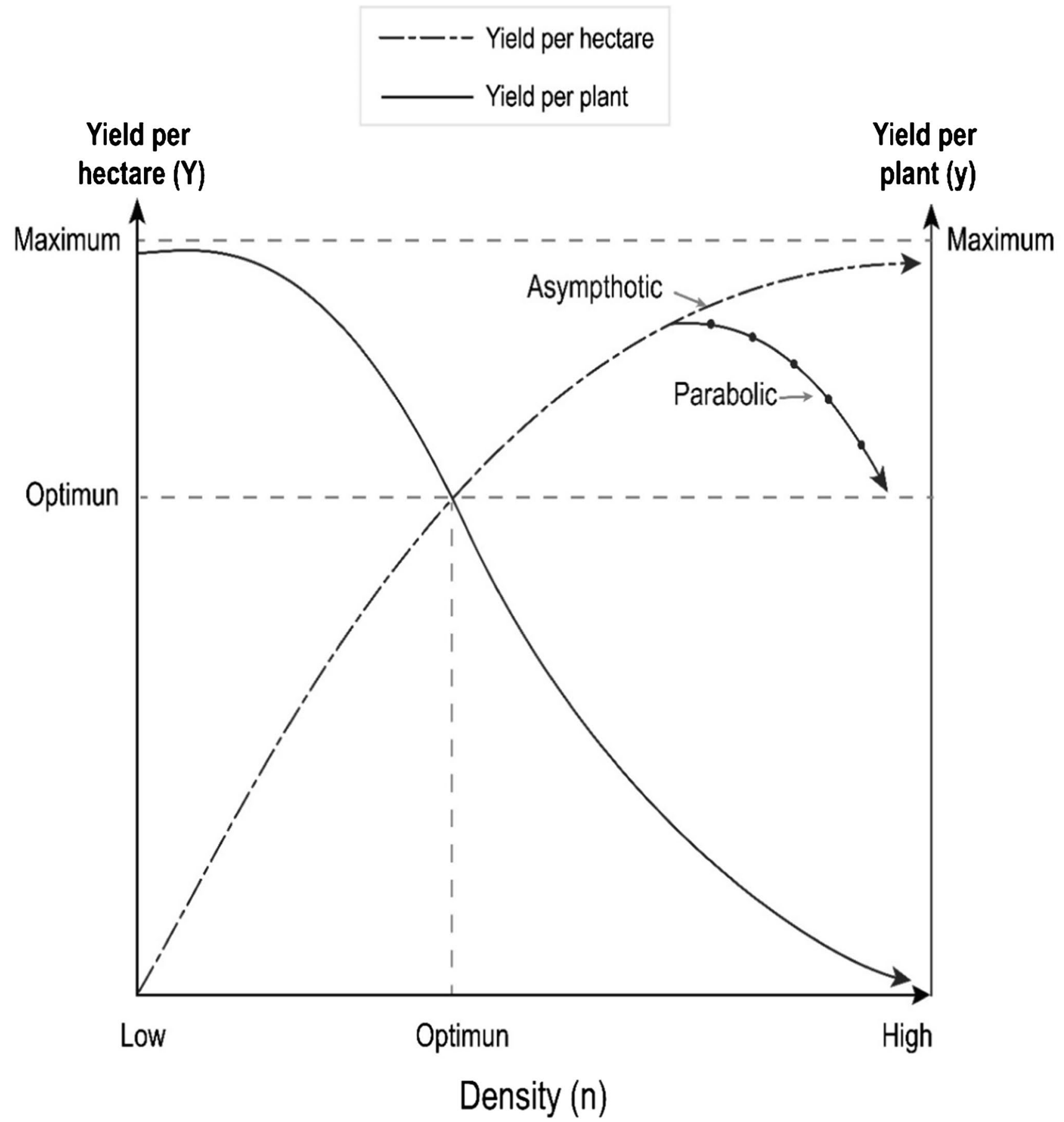

Fig. 3 Yield-density relationships in plant populations. Yield per hectare $(Y)$ and yield per plant $(y)$ are both affected by plant population density $\left(n=\right.$ plants $\left.\mathrm{ha}^{-1}\right)$.

1644 plants ha ${ }^{-1}$, but it varies significantly between cocoagrowing regions and orchard life cycle trajectories (Jagoret et al. 2011, 2018).

A planting density of 1680 trees ha $^{-1}$ appears to be the preferred planting density for cocoa in West and Central Africa because the canopy of cocoa closes rapidly, reducing the cost of weeding and facilitating harvesting and fumigation against capsids (Sahlbergella singularis Hagl. and Distantiella theobroma Dist.) (Charles 1961; Smith 2015). Climate change is now prompting farmers to plant drought-resistant cocoa at higher planting densities to compensate for higher plant mortality rates due to excessive heat and drought (Asante et al. 2017). Planting cacao at high densities in poor soils, such as those in West Africa, seems 
to be a sound strategy (Charles 1961). At high planting density, cocoa pods are concentrated on the trunk and not on the branches (Kowal 1959; Pacheco et al. 2003), and because of the tight closure of the cocoa canopy, there is no need for regular, intensive pruning or removal of suckers. Similar findings have been reported for Malaysia (Blencowe and Hubbard 1972).

\subsection{Yield plasticity, minimal critical density and the 'evolving cocoa planting density' concept}

In fully stocked cocoa orchards (using the representative cocoa population densities of either the Plantation or the Farmer Model), the elimination (as a result of prescribed thinning or natural mortality) of a number of trees (i.e. a decrease in density) may not result in a decrease in yield per hectare because the canopy space freed up by the cocoa trees removed is rapidly exploited by residual, neighbouring cocoa trees, which attain higher per plant yields that compensates for the yield loss from removed/dead trees (Bastide et al. 2008; Smith 2015; Vernon 1971). This compensatory pattern is maintained until the crowns of the residual trees can no longer utilise the space freed up by reductions in density, yield per plant stagnates and no longer compensates the yield loss due to removed trees. Below this 'minimal critical density', yield per hectare decreases as density decreases (Laryea 1969; Smith 2015). The actual minimal critical density is context specific. For instance, in an industrial cocoa plantation in Indonesia, initially planted at 1250 trees $\mathrm{ha}^{-1}$, the compensatory effects are still operational at 20 years of age, when the density has fallen to 835 trees ha $^{-1}$ (Bastide et al. 2008). Vernon (1971) cites 950 trees ha ${ }^{-1}$ as the minimal critical density. In Nigeria, this figure is 1450 trees $\mathrm{ha}^{-1}$ (Kowal 1959). Below the minimal critical density, the cocoa canopy of the orchard will have permanent 'holes' that become foci for weed invasion, attacks of pests and diseases, thus creating unfavourable microclimate conditions for the growth and yield of the cacao trees in their vicinity. The maintenance of a closed canopy is the most important factor in the life of a cocoa orchard (Vernon 1971).

The 'evolving cocoa planting density' concept has been proposed to denote a management model that prescribes reductions in planting density at various plantation ages both to increase per plant area (larger crowns) and keep low levels of inter-plant competition (at the soil level) to maintain high yields (Lachenaud 2003; Lass 1985). There is some evidence of gains in yields with this cocoa density management model (Armstrong 1976; Wood 1964). For instance, thinning of $50 \%$ at 10 years of age in plantations established initially at 1666 trees ha ${ }^{-1}$ produced favourable responses in yields both per plant and per area (Bastide et al. 2008).

\subsection{How does density change with age?}

Cocoa plants in a new orchard are all same-aged (a cohort) and will pass through the same life cycle stages, but not all will die at the same time. After an initial period of zero natural mortality ( $z$, the length of this zero-mortality period, is variable), the population size of the cohort will decrease with age at an annual, compound rate of less than $2 \%$ due to natural or random mortality (Lass 1985; Vernon 1971). The density of the initial cocoa cohort in any year $\left(P_{t}\right)$ can be described with Eq. (4).

$P_{t}=\left\{\begin{array}{c}P_{0}(1-r)^{t-z} \text { if } t \geq z \\ P_{0} \text { otherwise }\end{array}\right.$

where $P_{t}$ is the surviving trees at time $t, P_{0}$ is the initial planting density at time zero, $r$ is the mortality rate, $z$ represents the age at which the natural mortality starts affecting the tree population.

Long-term studies (say, $60+$ years) of changes in cocoa density in orchards with different cocoa genotypes and in different agro-environments are extremely rare. We can use Eq. (4), field data and expert knowledge to model cocoa mortality patterns in different agro-environments, to predict cocoa density and to estimate mortality rates from published studies. For instance, at a mortality rate of $2 \%$ and an initial period of 10 years of zero mortality, an orchard starting with 1000 plants ha $^{-1}$ will have 552 plants ha $^{-1}$ when 40 years old. Mortality rates can be estimated from cocoa density and age data reported in several studies. For example, a 22-yearold cacao plantation in Ghana still had $100 \%$ of the individuals from the initial cohort. However, at 30 years, $84 \%$ of the initial population remained; at 40 years, $50 \%$ remained and at 50 years, only $26 \%$ of the initial cohort remained (Laryea 1969; Vernon and Morris 2015). In Costa Rica, a 40-yearold cacao orchard retained $70 \%$ of the trees from the initial cohort (Martin 1957). In West Papua, Indonesia, an industrial cocoa plantation, initially planted at 1250 cocoa plants ha $^{-1}$, had 835 plants ha ${ }^{-1}$ at the age of 22 years (Bastide et al. 2008). If the relationship between population size and age follows Eq. (4), the estimated average annual rate of mortality $(r$, for $t>z)$ is $0.887 \%$ for Costa Rica, $4.697 \%$ for Ghana and $1.817 \%$ for Indonesia. Natural mortality affects cocoa yields very differently, depending on the initial planting density, i.e. high impact in yield in the Plantation Model and low impact on yield in the Farmer Model cocoa orchard. An annual, natural mortality rate of $2 \%$ has insignificant effects on a Farmer Model orchard (Charles 1961), but it has a devastating impact on a Plantation Model orchard. 


\subsection{How does yield change with age?}

Although biologically a cacao tree can live for more than 100 years, the economic life of a cocoa orchard (if not rehabilitated) lasts typically 30-40 years (Akinnagbe 2017; Gotsch and Burger 2001; Obiri et al. 2007; Montgomery 1981; Lass 1985). However, the economic life of an orchard is highly variable and context specific. Site quality, germplasm and orchard management have important effects on the form of the yield-age curve of cocoa (Wessel 1969). For instance, traditional orchards in Ghana have an economic life cycle of 50-80 years, but for hybrid cocoa, with or without timber shade, the economic optimum has been estimated at 29 and 18 years, respectively (Obiri et al. 2007; Mahrizal et al. 2014). There is no single yield-age curve for cocoa that applies everywhere (Dias et al. 2003; Spaggiari Souza et al. 2009; Vigneri 2007; Ahenkorahh et al. 1987; Upton 1966; Laryea 1969; Lass 1985; Ruf 2011; Smiley and Kroschel 2009; Montgomery 1981). For example, in Malaysia, cocoa starts yielding in the third year of age $\left(400 \mathrm{~kg} \mathrm{ha}^{-1}\right)$, rising to an average (typical) yield by year 15 $\left(950 \mathrm{~kg} \mathrm{ha}^{-1}\right)$; yields are maintained until 30 years of age and then decline rapidly until 40 years of age, when they are barely $200 \mathrm{~kg} \mathrm{ha}^{-1}$ (Gotsch and Burger 2001). In some cocoa-growing areas, without rehabilitation practices, drops in yields were reported over time. Laryea (1969) estimated a $20 \%$ drop in yields in cocoa orchards over 30 years of age. Other studies report yield decline after 20 years of age in Nigeria (Vernon and Morris 2015), and after 15 or 20 years of age in Ghana (Ofori-Bah and Asafu-Adjaye 2011; Aneani et al. 2017). In Cote d'Ivoire and in Ghana, cocoa orchards planted in sites with low fertility degrade at 10-15 years of age (Ahenkorahh et al. 1987; Assiri et al. 2003). On good soils, production stabilises at 10 years of age and yields start declining at 30 years of age, at an average rate of $1 \%$ per year. Some cocoa orchards maintain acceptable yields up to 40 years of age in Cameroon when rehabilitation practices are applied (Jagoret et al. 2011).

A few yield-age functions have been published for cocoa. For instance, Ryan et al. (2009) used

$y_{t}=e^{(-1.1-0.125 t+\ln (t))}$

where $y=$ dry cocoa bean yield $\left(\mathrm{kg}\right.$ tree $\left.\mathrm{e}^{-1}\right), e$ is the base of natural logarithms, ln is natural logarithm and $t=$ age in years.

Obiri et al. (2007) used the model developed by Ryan et al. (2009) and re-scaled it to an 80-year cycle for traditional cocoa cultivation in Ghana.

$Y_{t}=e^{(-1.822-0.166 t+3.931 * \ln (t))}$

where $Y_{t}=$ dry cocoa bean yield $\left(\mathrm{kg} \mathrm{ha}^{-1}\right)$, and adjusted regression parameters for two plantation models using hybrid cocoa, with shade,

$Y_{t}=e^{(1.6399-0.18 t+2.924 \ln (t))}$

and without shade,

$Y_{t}=e^{(0.0992-0.4 t+4.745 \ln (t))}$

The graphical representation of Eqs. (6), (7) and (8) is given in Fig. 4.

Most cocoa farmers continuously rejuvenate their orchard by both replanting empty planting sites and managing the trees' live tissues. The latter includes stumping, pruning, and grafting old and diseased cocoa plants to regulate the crown shape and tree size (Jagoret et al. 2011, 2017b). These practices transform the single-cohort orchard initially planted into a multi-cohort orchard (with each cohort yielding according to its age) with young, productive tissue (Jagoret et al. 2011, 2017b). As a result of these plant and tissue age structures, the $y(t)$ curve is 'lifted upward', extending the economic life of the orchard (see Fig. 5). $R_{\min }$ is the minimum acceptable yield tolerated by farmers, which usually depends on context conditions, including markets and production cost. $R_{0}$ is the maximum attainable yield of the orchard with current technology.

\section{Rehabilitation and renovation practices}

Cocoa agronomists and farmers have at their disposal an extensive list of practices for rehabilitation and renovation (Lass 1985). This list includes complete replanting of the orchard, replanting in stages, selective replanting of trees, planting new cacao under old cacao used as temporary shade, reconstructing cocoa tree crowns using basal suckers, with or without grafting them, various types of pruning and pollarding to regulate cocoa crown's shape and size, replanting, stumping, propagating elite trees, shade regulation, early intercropping, etc. (Akinnagbe 2017; Are and Jacob 1971; Ogunniyi and Osuolale 2015; Wessel and QuistWessel 2015; Asare and David 2010). Several authors have provided lists of the different models for rehabilitation and renovation, and their variants, in different cocoa-growing regions (Assiri et al. 2003; Ampofo and Osei-Bonsu 1987; Ogunniyi and Osuolale 2015; Olaiya et al. 2006; Are 1969b, 1970a; Quiroz and Amores 2002; Lass 1985).

Rehabilitation practices include (1) stumping and sucker selection to regenerate the crown of the cocoa tree (Akinnagbe 2017; Riedel et al. 2019); (2) stumping combined with top or patch grafting (with a new cocoa genotype) on the regenerated suckers; (3) restocking the orchard by direct seeding, planting nursery seedlings, rooted stakes or grafted plants at empty planting sites 
Fig. 4 Age $\times$ yield curves for different cocoa systems (Obiri et al. 2007).

\section{Dry cocoa bean}
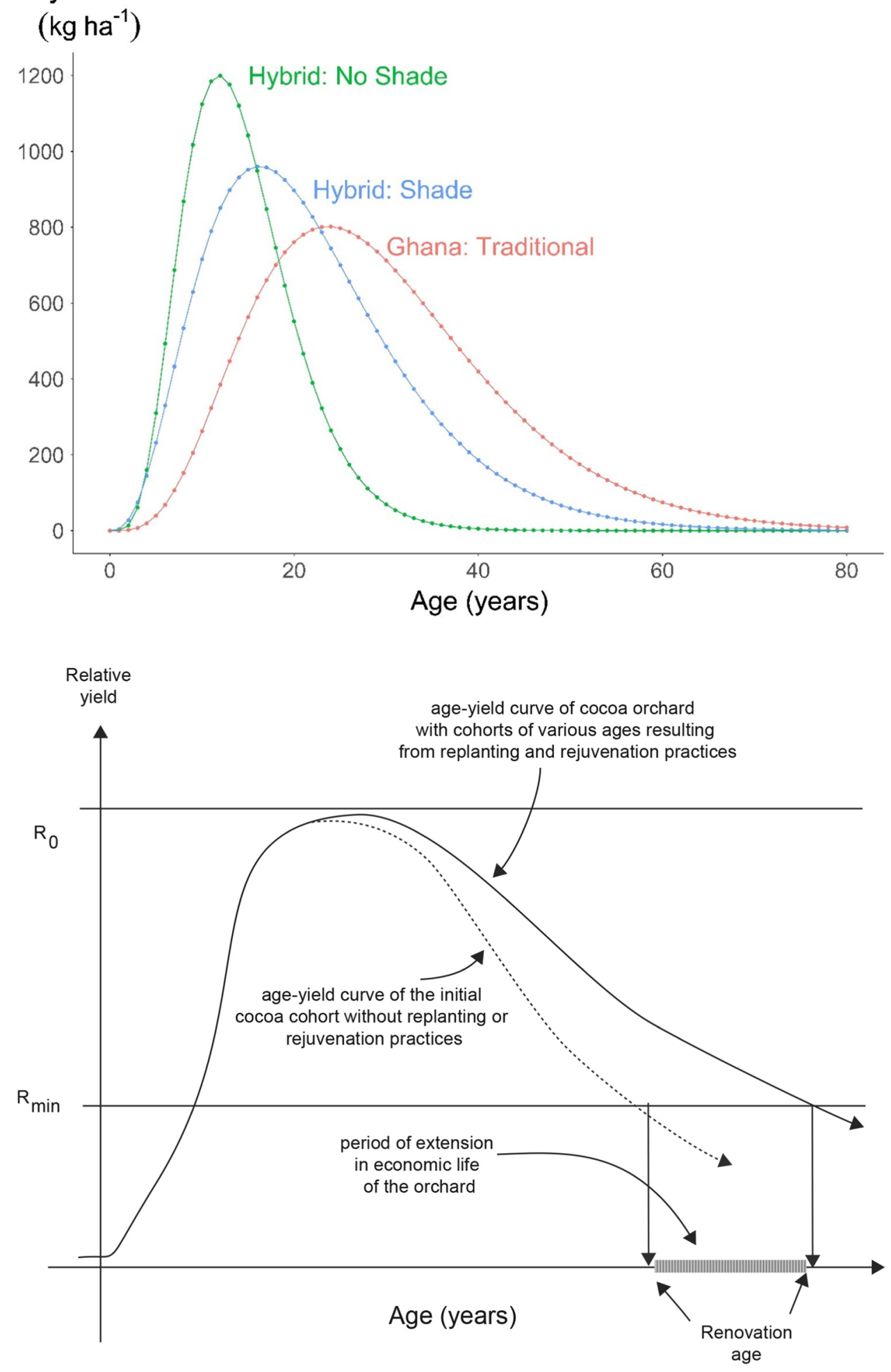

Fig. 5 Impact of continuous rejuvenation of cocoa tissue plants in the age of renovation of a cocoa orchard. $R_{\min }$ is the minimum acceptable yield tolerated by farmers, which usually depends on context conditions, including markets and production cost. $R_{0}$ is the maximum attainable yield of the orchard with current technologies.
(Asare et al. 2018); and (4) complete removal of the crown by pollarding to remove diseased tissue or to reduce tree height (Are 1969b; Grisales and Cubillos 1985; Quiroz and Amores 2002; Olaiya et al. 2006). In Central Cameroon, the rehabilitation practices adopted by farmers are largely responsible for the presence of very old cocoa agroforestry systems that continue to be exploited today. The continuous replacement of dead cocoa trees and the cutting back of senescent cocoa trees rejuvenate the cocoa stand (Jagoret et al. 2018). Farmers' management of shade 
trees is in continuous evolution, in terms of both density and species composition. Species selection is based on minimising competition and promoting complementarity between cocoa trees and associated tree species (loc. cit.). The rehabilitation of a commercial, clonal, open-sun cocoa plantation in Malaysia using agroforestry and soil amendments has been documented by Vanhove et al. (2016).

Renovation typically seeks the construction of a new cocoa orchard, with cocoa cohorts and a shade canopy that may be very different from the original. Three major categories of renovation models can be identified: (1) selective (or partial) renovation; (2) staggered (or phased) renovation, when a fraction of the orchard is replaced periodically; (3) total renovation, cutting and eliminating everything at the same time to establish the new cocoa orchard (Olaiya et al. 2006; Lass 1985). Most available information focuses on types 2 and 3 renovation models.

In selective or partial renovation, farmers replace all poor-yielding trees over the entire life cycle of the cocoa orchard (Lass 1985). The disadvantages of this method (possible spread of cocoa swollen shoot virus and other diseases from the existing trees to the new plantings and high labour requirement) seem to outweigh its advantages (income generation can continue while replanting is in process and no new land is required) (Mahrizal et al. 2014). In the staggered model, a fraction of the cocoa plants are renovated periodically, aiming at achieving an age-structured cocoa population that both results in a constant annual flow of benefits and spreads investments over the renovation period (Ampofo and Osei-Bonsu 1987; Obiri et al. 2007; Mahrizal et al. 2014). In this model, cocoa yields from the residual plants increase in response to the thinning of the neighbouring cocoa plants, pruning and management (Enríquez and Paredes 1981; Soria and Garcia 1968). Weeds are not a problem because the soil is always shaded by residual cocoa trees. Also, there is no need to plant and manage temporary shade, and shading by the yet-to-be-removed cocoa plants may reduce capsid or mirid attacks (Laryea 1969; Vello et al. 1971) or increase attack by viruses and fungi (Dzahini-Obiatey et al. 2006). However, the shading of the new plants may be irregular (Are 1969a, 1970a) and the opportunities for early intercropping are reduced. Many variations on the temporal model (to distribute risk, financial investment and secure a constant flow of income) and the spatial staggering model (by rows, by sectors, by groups of trees, etc.) have been presented (Lass 1985). In the total renovation model, the financial investment is high (Vello et al. 1971; Martin 1957). No income from cocoa sales is obtained for up to 5 years until cocoa production resumes, but significant income may be obtained from both the sale of timber and early intercropping.

\section{The cocoa agroforestry renovation approach}

The life cycle of a cocoa agroforestry orchard involves four components (Fig. 6). First is the period of site restoration (e.g. soil fertility and health) to sustain a new cultivation cycle of cocoa. Second is site preparation, planting of cocoa and early intercropping with short-term crops to generate early revenues and reduce the need for investment capital to establish the new orchard. Third is the cocoa stand, with its various cohorts, varied genetic compositions and its context-dependent age-yield-density behaviour. Fourth is the shade canopy, with varied botanical compositions and three-dimensional spatial structures. Two or more cultivation cycles can take place in one site. In Fig. 6, the yields of all components are scaled to any locally determined maxima (on an ordinal, relative scale). The $x$-axis is the age in years. Three cocoa yield threshold levels are represented: (1) minimum acceptable yield level, which tells farmers when to renovate $\left(R_{\min }\right)$; (2) maximum yield level with current technology $\left(R_{0}\right)$; (3) maximum yield level with new technology $\left(R_{1}\right)$. In the following sections, we explore in more detail each component of the model.

Figure 6 represents a cocoa agroforestry model that includes (1) a 5-year period to restore the fertility of the site; (2) a 3-year period for land preparation, planting cocoa and early intercropping with food crops; (3) cocoa over the entire cultivation cycle; and (4) the shade canopy (over the entire cultivation cycle), made up of fruit and timber trees, which are all planted and removed at the same time, at age 35 years. Timber trees are planted at low density when cocoa is planted, and then no intermediate thinning is required. The evolution of cocoa yields over time has been explored in previous sections of this review. A more detailed description of the other components of the approach is presented in what follows.

\subsection{Site restoration}

Farmers prefer to establish new cocoa orchards on recently cleared forest land because of better soil fertility and to avoid the burden of both removing the old cocoa orchard and restoring soil fertility when attempting to replant at the same site. The term 'forest rent' has been coined to describe the high soil fertility levels experienced when cocoa is established in recently cleared forest lands (Asare et al. 2018; Laryea 1969; Ruf and Zadi 1998; Trivedi 1988). Cocoa is usually cultivated without the application of fertilizers (organic or inorganic) to replace the nutrients exported in the cocoa beans; thus, the soil nutrient pool of 


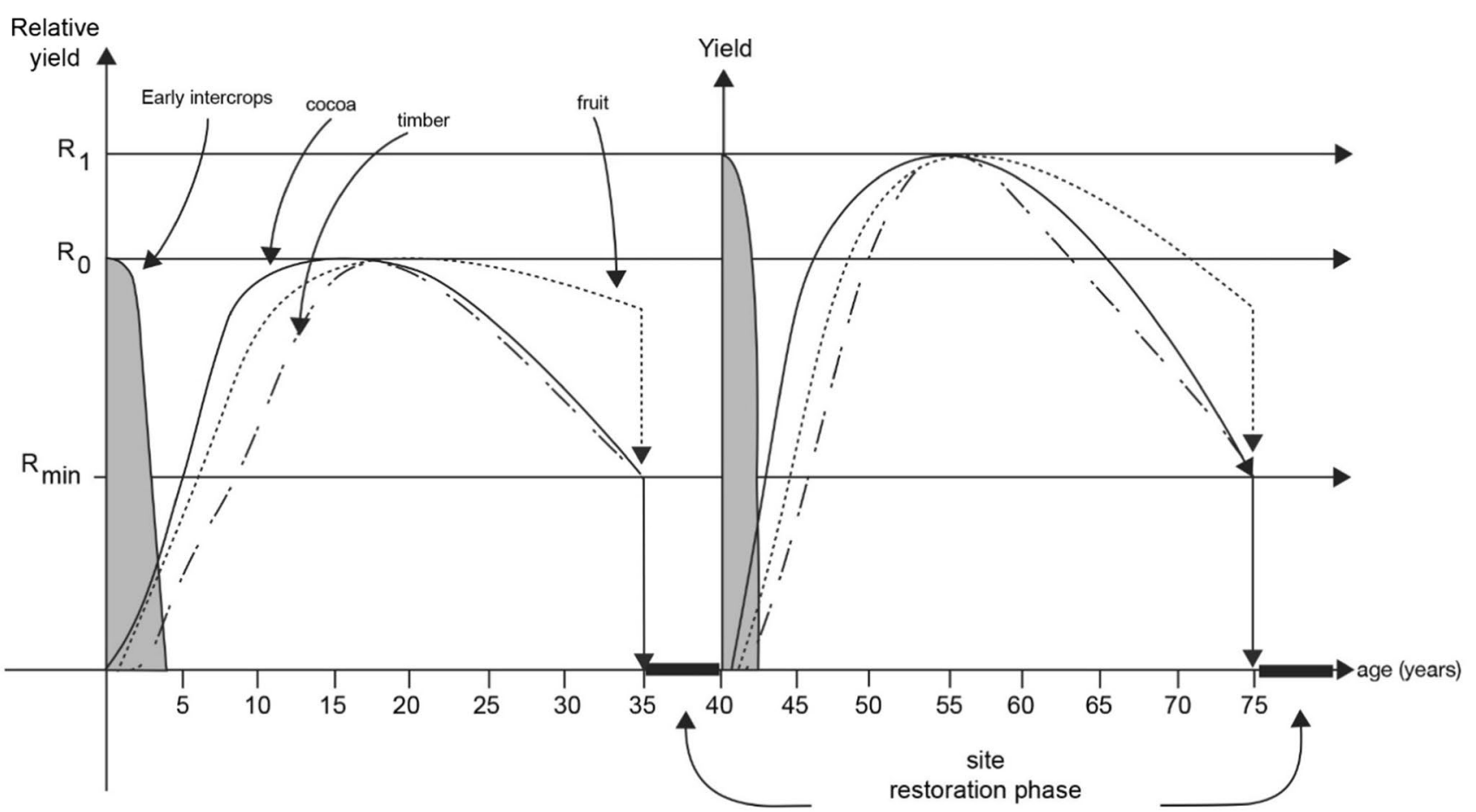

Fig. 6 Age-dependent trends in all components of the cocoa agroforestry renovation model that includes three components: (1) a 5-year period to restore the fertility of the site and to prepare the site for the planting of an agroforestry system; (2) a period of 1-3 years of early intercropping where short-term crops are cultivated; (3) cocoa, fruit and timber trees are all planted and removed at the same time, at

the site is mined out during the cultivation cycle of cocoa (Ahenkorahh et al. 1987; Wessel and Quist-Wessel 2015; Jagoret et al. 2011). Various studies document both the difficulty experienced by farmers when attempting to replant cocoa after a 40-year cycle of non-fertilized cocoa, and the need to restore the fertility of the soil before a new cocoa orchard is planted (Asare and David 2010; Assiri et al. 2012; Wessel 1969). The difficulties are notorious in poor soils, which may require the planting of improved fallows, cover crops and other soil fertility remediation measures for several years before cacao can be planted again (Assiri et al. 2003; Anim-Kwapong and Osei-Bonsu 2009; AnimKwapong 2003; Anim-Kwapong and Teklehaimanot 1995; Are 1969b, a; Are and Longworth 1965; Ayanlaja 1983; Petithughenin 1995).

\subsection{Early intercropping}

Early intercropping with short-term crops is a well-established practice in cocoa cultivation worldwide, with proven benefits in household food consumption, early financial returns resulting in a better long-term financial performance, and enhanced survival and early growth of the cocoa age 35 years. Fruit and timber trees are used for shade. In the second cycle, an improved agroforestry model replaces the original cocoa agroforestry orchard. The $x$-axis is the age in years. Three threshold levels are depicted: (1) minimum acceptable yield level $\left(R_{\min }\right)$-it tells farmers when to renovate; (2) maximum yield level with current technology $\left(R_{0}\right)$; (3) maximum yield level with new technology $\left(R_{1}\right)$.

seedlings. Weeding, fertilisation and other amelioration practices applied to the intercrops directly benefit the early establishment of both cacao and planted shade trees (Adeyemi 1999; Egbe and Adenikinju 1990; Mahrizal et al. 2014; Oladokun 1990; Melendez 1991). The financial impact of early intercropping is rarely (if ever) considered in $\mathrm{Rh} / \mathrm{Re}$ decision-making; with some notable exceptions (Mahrizal et al. 2014; Obiri et al. 2007).

\subsection{The shade canopy}

Cocoa shade canopies are structurally and functionally diverse, with one or many tree species, each with its own population size, age and size frequency distribution, yields (timber, fruit, firewood, maintenance of soil fertility, store carbon, protect the soil from erosion, etc.), temporal dynamics, spatial planting patterns, vertical stratification of tree crowns and use-values (Wessel and Quist-Wessel 2015; Jagoret et al. 2014). Cocoa shade canopies are usually grouped into six broad typologies (Somarriba and Lachenaud 2013), each one reflecting the goals and needs of the farmer, e.g. to produce only cocoa (as is the case in open sun orchards and in shaded systems in which the shade species only produces 
shade) or also to produce fruit, timber, medicine, etc. (Obiri et al. 2007).

\section{Climate-smart cocoa agroforestry $\mathrm{Rh} / \mathrm{Re}$}

A growing body of research describes how much and where air temperature, rainfall, wind, $\mathrm{CO}_{2}$ concentration, and other atmospheric and meteorological variables will change over the next 30 or 50 years in all cocoa production regions (Schroth et al. 2016b; Bunn et al. 2019a; Läderach et al. 2013). Expected climatic changes in cocoa regions include a rise in temperature, changing precipitation levels and patterns, and recurrent stressful events (e.g. drought or flooding) leading to tree death, changes in phenology, shortening of the life cycle of important cocoa pests and diseases, and decrease in yields (Leandro-Muñoz et al. 2017; Bertolde et al. 2012; Gateau-Rey et al. 2018; Granados Ramírez and Pérez Sosa 2020). Knowledge of cocoa physiology and agronomy dictates what is possible in terms of cropping cocoa under climate change (Lahive et al. 2018). Impacts of climate change on current and future cocoa production areas and supply chains in key cocoa geographies have been predicted and mapped to help farmers, extension services, land-use planners and decision-makers transition to a climate-smart cocoa sector at various scales (Bunn et al. 2019b). There is room for improving predictions by taking into consideration the physiological plasticity of cocoa to changing climatic conditions as well as the untapped potential of genetic diversity in the response of cocoa to climate change stresses (Lahive et al. 2018).

The impacts of climate change on cocoa cultivation areas create a patchwork of situations. At some locations, currently suitable cultivation areas may become marginal or completely inadequate for growing cocoa, forcing farmers to shift to other crops (Schroth et al. 2016b; Read 2019). At other locations, areas previously unsuitable may become acceptable or even optimal for growing cocoa. For instance, in Cote d'Ivoire and Ghana, increasing temperatures will shift optimal elevations for cocoa (Läderach et al. 2013) and force farmers to use shade trees wisely as a key adaptation measure (Schroth et al. 2016b). Pest and disease outbreaks, now powered by climate change, have led to the downfall of entire cultivation areas and have shaped the global geography of the cultivation of cocoa (Cilas and Bastide 2020). Increasing temperatures are forcing coffee farmers in Central America to shift cultivation areas to higher elevations, opting for cocoa to replace lowland coffee (Läderach et al. 2017; de Sousa et al. 2019).

Adoption of climate-smart cocoa farming strategies and practices that simultaneously address (at least) profitability, resilience and low GHG emissions is much needed. Farm diversification, agroforestry, the use of improved genotypes of both cocoa and associated crops, irrigation, fertilisation, soil organic matter and cover, integrated pest management, intensification and other good crop husbandry practices have all been recommended as key adaptation and mitigation measures to cope with climate change (Gusli et al. 2020; Denkyirah et al. 2017; Jagoret et al. 2012). The use of shade trees (i.e. agroforestry) stands out as a widely recommended adaptation and mitigation measure (Andres et al. 2018; Schroth et al. 2016b; Kroeger et al. 2017). Other studies have assessed farmers' perceptions and coping measures in the face of climate change such as the application of innovative crop management practices (Asante et al. 2017; Denkyirah et al. 2017; Oyekale and Adepoju 2012; Jacobi et al. 2013; Codjoe et al. 2013; Oluwatusin 2014), the estimation of the right amount of subsidies to compensate farmers for the risks involved when adopting climate-smart practices (De Pinto et al. 2013), and the need for certification and better prices to promote the use of shade (Middendorp et al. 2018).

Recommendation domains, based on the level of expected change in land suitability and the degree of transformation in cocoa farming needed to cope with these changes, have been proposed as an analytical and planning tool to help design optimal transition pathways for cocoa under climate change (Bunn et al. 2019b). Transitions in land suitability from optimal to acceptable to marginal (or vice versa) will require climate-smart cocoa agroforestry $\mathrm{Rh} / \mathrm{Re}$ models, strategies and practices (Kroeger et al. 2017; Read 2019). It is proposed that a climate-smart cocoa agroforestry $\mathrm{Rh} / \mathrm{Re}$ decision-making and implementation process, which identifies threats and response measures, should be tailored to the four components of the cocoa cultivation cycle: (1) site restoration; (2) plantation establishment and early intercropping; (3) cocoa; (4) shade canopy. For instance, the erratic onset of rains may be fatal to cocoa seedlings during the establishment and early intercropping phase, so the use of improved cocoa genotypes has been recommended to reduce seedling mortality during the dry period (Padi et al. 2013). Fires are especially fatal for young cocoa. In the forest-savanna transition zone in West Africa, farmers losing a young cocoa plot to fires may shift to other crops, giving up cocoa cultivation (Asante et al. 2017). Droughts can also kill adult cocoa trees (Gateau-Rey et al. 2018).

The threats posed by climate change and the adaptation measures needed during the productive phase (cocoa and shade canopy) of the cocoa cultivation cycle are manifold and poorly understood. For example, in their summary of 80 years of CSSVD research and eradication campaigns in Ghana, Andres et al. (2017) concluded that the "effects of commonly used shade tree species on mealybug populations and CSSVD infection have not been investigated so far, and they may vary depending on shade tree species. It is difficult to identify adequate shade levels and tree species composition that minimise mealybug populations and thus likelihood 
of CSSVD infection while ensuring favourable growing conditions for cocoa trees. This is because optimal shade levels for cocoa trees and mealybug populations vary over the year. Therefore, more research on effective agroforestry designs to combat CSSVD is needed'. Recent studies have looked at the effect of the spatial distribution of shade trees on the spatial distribution of cocoa mirids (Babin et al. 2010; Gidoin et al. 2014) or the role of shade trees as barriers to the dispersal of mealybugs transmitting CSSV (Andres et al. 2017).

Few studies have been published on the long-term changes in the botanical composition, total biomass, value, timber stock, etc. of cocoa shade canopies, with some notable exceptions. For instance, Frimpong et al. (2003) and Obiri et al. (2007) reported reductions in total carbon stock with shade canopy age in Ghana. Jagoret et al. (2017a) and Jagoret et al. (2018) documented increments in cocoa basal area and a decline in the basal area of shade trees with the aging of the orchard. Standing carbon seems to increase as the plantation ages in Cameroon (Saj et al. 2013, 2017). Equally unknown is the yield-age function of most shade tree species in cocoa orchards in different agro-environmental and cultural contexts. More research is warranted.

A growing body of research focuses on the development and use of methodologies and tools to aid in the optimal design of cocoa shade canopies (Somarriba et al. 2018, 2020; Álvarez-Carrillo et al. 2012; Malézieux 2012; Guharay et al. 2001; Tscharntke et al. 2011). This is a most welcome development since most cocoa shade canopies are sub-optimal in terms of species composition, stand density and homogeneity in the spatial distribution of canopy cover (Somarriba et al. 2018). Preliminary evidence suggests that, with proper design, it is possible simultaneously to achieve livelihood goals (profit and reduced financial vulnerability, food security) at the same time as environmental goals (e.g. store significant amounts of carbon in shade tree biomass, reduce input-related emissions, mostly from fertilizers) (Schroth et al. 2015b; Somarriba et al. 2013; Middendorp et al. 2018). Six rules for shade management in cocoa agroforestry systems have been proposed, involving the inclusion of $\mathrm{N}$-fixing legumes, periodic pruning, diverse botanical composition with multiple vertical strata, and combining food and cash crops, for which optimal shade design and management is required (Tscharntke et al. 2011). Others suggest the use of basal area ratios between shade canopy trees and other components. A Cameroonian cocoa agroforestry system has been proposed as an indicator of long-term sustainability (Saj et al. 2017). This review suggests that the synchronisation in time of yields of all products from the orchard (food crops, cocoa, shade tree products) is a central design goal in cocoa agroforestry systems. This is not an easy task since several factors militate against synchrony. For instance, the life cycle of cocoa and shade canopy plants differ, trees may be planted or recruited from natural regeneration in different years, and even when cocoa and shade canopy trees are planted simultaneously (as in Fig. 6), they may not be harvested simultaneously due to differences in their yield-age relationships. For instance, fruit trees may start fruiting between 3 and 5 years of age and sustain productivity for decades. Timber trees may be harvested at the same time cocoa trees are renovated (30 years in Fig. 2, also see Obiri et al. 2007) or not. For instance, timber trees in cocoa shade canopies in Central America have size (and age) structured populations because recruitment, natural mortality and harvest occur continuously (Somarriba et al. 2014).

\section{Conclusions}

Rehabilitation and renovation $(\mathrm{Rh} / \mathrm{Re})$ are essential elements in the cocoa cultivation cycle. Cocoa agronomists have devised methods and protocols to assess the $\mathrm{Rh} / \mathrm{Re}$ needs of a cocoa orchard, and to make decisions regarding whether to rehabilitate, renovate or not at all, as well as how much and when to do it. Current $\mathrm{Rh} / \mathrm{Re}$ decision-making processes are based on the assessment of the age, planting density and yield of only the cocoa component of the orchard. The regular flow of food crop and tree products for sale or family consumption, and the need to restore site (soil) quality to sustain another cycle of cultivation of cocoa at the same site, are not considered in current $\mathrm{Rh} / \mathrm{Re}$ diagnosis and design protocols. Furthermore, farmers are usually reluctant to follow technical recommendations to engage in $\mathrm{Rh} / \mathrm{Re}$ because of the financial burden involved, and the uncertainty and risks of adopting new, yet unproven, climate-smart production practices.

In this review, we propose an agroforestry Re approach that overcomes these limitations by incorporating not only the production of cocoa but also of food crops and tree products, and the need to restore site quality to enable another cultivation cycle of cocoa at the same site (and hence reduce pressure on natural forests). Intercropping with short-term food crops, agroforestry, and site restoration are three common practices in cocoa farming worldwide, but their contributions to the Re decision-making and implementation process are rarely (if ever) considered. This review sheds light on these important issues and shows how to overcome current limitations.

Rehabilitation and renovation of cocoa agroforestry systems is central to any transition towards profitable, climate-smart cocoa production. Our review shows that $\mathrm{Rh} /$ Re decision-making and field implementation processes are complex, context-specific (agronomic, social, climate, etc.) and hence unique processes. To guide farmers, extension agents, land use planners and decision-makers in this complex process, we need a solid body of science- and expertbased knowledge to support decisions and innovation design 
at every step of the transition towards profitable and climate-smart cocoa production. Unfortunately, we have only a rudimentary understanding of the processes and interactions between cocoa and the shade canopy. We need more research on (at least).

- The optimum amount of aboveground carbon that each typology can store (without sacrificing profits) along cocoa cultivation altitudinal, latitudinal, rainfall and soil quality gradients.

- The critical rainfall thresholds that determine whether the presence, kind and amount of shade trees in a cocoa agroforestry system is beneficial or detrimental to the output of the system. Regulation of shade canopy biomass (by pruning, thinning, planting) have direct effects on air temperature (and heat stress) and water use.

- How yield-losses to pests and diseases vary with shade canopy design. Interactions between shade, microclimate, pests and disease dynamics are complex and poorly understood.

- How primary productivity of cocoa shade canopy typologies affect the rate of restoration of site quality, in different soil, climate and culture contexts.

- The effect of synchrony (or lack thereof) on yields among shade trees, and between them and cocoa, on the optimisation of the $\mathrm{Rh} / \mathrm{Re}$ process.

- The density-yield-age curves for the most common species of shade trees used in different cocoa agroecological and cultural contexts.

The analysis of the factors influencing $\mathrm{Rh} / \mathrm{Re}$, the agroforestry Re approach herein presented, and the best practices and interactions with climate change described for cocoa may also be applicable to coffee agroforestry systems.

Acknowledgements Thanks to the anonymous reviewers for their constructive criticisms and suggestions to improve the quality of the manuscript. Kate Roberts copy-edited and proof-read the manuscript.

Authors' contributions Conceptualisation: E.S. and F.S. Methodology: E.S., R.C. and F.P. Writing — original draft: E.S. Writing - review and editing: E.S., F.P., R.C., L.O.A., A.L.S, M.E.L.M. and P.J. Funding acquisition: E.S. and F.S. Supervision: E.S. All authors read and approved the final manuscript.

Funding This research was funded by the CGIAR research program on Forests, Trees and Agroforestry (FTA), CATIE, CIRAD, Lutheran World Relief (MOCCA Project) and Ministerio de Educación Superior, Ciencia y Tecnología (MESCYT, Proyecto 031-2015 código 20152D1-191) of the Dominican Republic.

\section{Declarations}

Data availability (data transparency) Not applicable.

Code availability (software application or custom code) Not applicable.
Conflict of interest The authors declare no competing interests.

Ethics approval Not applicable.

Consent to participate Not applicable.

Consent for publication Not applicable.

Open Access This article is licensed under a Creative Commons Attribution 4.0 International License, which permits use, sharing, adaptation, distribution and reproduction in any medium or format, as long as you give appropriate credit to the original author(s) and the source, provide a link to the Creative Commons licence, and indicate if changes were made. The images or other third party material in this article are included in the article's Creative Commons licence, unless indicated otherwise in a credit line to the material. If material is not included in the article's Creative Commons licence and your intended use is not permitted by statutory regulation or exceeds the permitted use, you will need to obtain permission directly from the copyright holder. To view a copy of this licence, visit http://creativecommons.org/licenses/by/4.0/.

\section{References}

Adebiyi S, Okunla J (2013) Factors affecting adoption of cocoa farm rehabilitation techniques in Oyo State of Nigeria. World J Agric Res 9(3):258-265. https://doi.org/10.5829/idosi.wjas.2013.9.3. 1736

Adeogun SO, Olawoye JE, Akinbile LA (2010) Information sources to cocoa farmers on cocoa rehabilitation techniques (CRTs) in selected states of Nigeria. J Media Commun Stud 21(1):9-15

Adeyemi AA (1999) Effective intercropping systems for young cocoa. Trop Sci 39:1-10

Ahenkorahh Y, Halm BJ, Appiah MR, Akrofi GS, Yirenkyi JEK (1987) Twenty years results from a shade and fertilizer trial on amazon cocoa (Theobroma cacao) in Ghana. Exp Agr 23:31-39

Aikpokpodion PO, Adeogun SO (2011) A diagnostic study of constraints to achieving yield potentials of cocoa (Theobroma cacao L.) varieties and farm productivity in Nigeria. J Agr Sci 3(4). https://doi.org/10.5539/jas.v3n4p68

Akinnagbe OM (2015) Evaluation of constraints to implementation and adoption of cocoa resuscitation programmes in Southwest Nigeria. Appl Trop Agr 20(1):42-47

Akinnagbe OM (2017) Impact of cocoa resuscitation programme on farmers' livelihoods in South West. Nigeria Agric Conspec Sci 82(1):39-47

Álvarez-Carrillo F, Rojas-Molina J, Rojas-Molina J, Suarez-Salazar JC, Suarez-Salazar JC (2012) Simulación de arreglos agroforestales de cacao como una estrategia de diagnóstico y planificación para productores. Corpoica Ciencia y Tecnología Agropecuaria 13(2):145-150. https://doi.org/10.21930/rcta.vol13_num2_art: 249

Alvim P (1964) Estudos sobre o espaçamento de cacau na África. Cacau Atual 1:1-6

Ameyaw GA, Dzahini-Obiatey HK, Domfeh O (2014) Perspectives on cocoa swollen shoot virus disease (CSSVD) management in Ghana. Crop Protect 65:64-70. https://doi.org/10.1016/j.cropro. 2014.07.001

Ampofo ST, Osei-Bonsu K (1987) Models for rehabilitating small scale cocoa farms in Ghana. In: Cocoa Producers Alliance (COPAL), 10th International Cocoa Research Conference, COPAL, Lagos, Nigeria, pp 51-55 
Andres C, Blaser WJ, Dzahini-Obiatey HK, Ameyaw GA, Domfeh OK, Awiagah MA, Gattinger A, Schneider M, Offei SK, Six J (2018) Agroforestry systems can mitigate the severity of cocoa swollen shoot virus disease. Agric, Ecosyst Environ 252:83-92. https:// doi.org/10.1016/j.agee.2017.09.031

Andres C, Gattinger A, Dzahini-Obiatey HK, Blaser WJ, Offei SK, Six J (2017) Combatting cocoa swollen shoot virus disease: what do we know? Crop Protect 98:76-84. https://doi.org/10.1016/j. cropro.2017.03.010

Aneani F, Adu-Acheampong R, Sakyi-Dawson O (2017) Exploring opportunities for enhancing innovation in agriculture: the case of cocoa (Theobroma cacao L.) production in Ghana. Sustain Agric Res 7(1):33. https://doi.org/10.5539/sar.v7n1p33

Aneani F, Padi F (2016) Baseline farmer survey of smallholder cocoa farming systems in Ghana. Sustain Agric Res 6(1):13. https:// doi.org/10.5539/sar.v6n1p13

Anim-Kwapong GJ (2003) Potential of some Neotropical Albizia species as shade trees when replanting cacao in Ghana. Agrofor Syst 58:158-193. https://doi.org/10.1023/A:1026097423351

Anim-Kwapong GJ, Osei-Bonsu K (2009) Potential of natural and improved fallow using indigenous trees to facilitate cacao replanting in Ghana. Agrofor Syst 76(3):533-542. https://doi. org/10.1007/s10457-008-9196-4

Anim-Kwapong GJ, Teklehaimanot Z (1995) Reclamation of degraded cocoa lands using Albizia Zygia. Land Degrad Rehabil 6:109123. https://doi.org/10.1002/ldr.3400060205

Are L (1969a) Methods used for rehabilitating old cacao farms in Nigeria. In: Cocoa Producers Alliance (COPAL), International Cocoa Research Conference, COPAL, Lagos, Nigeria, pp 383-387

Are L (1969b) Rehabilitation of cocoa farms. Part 1. Cocoa Grow Bull 13:11-13

Are L (1970a) Rehabilitation of cocoa farms. Part 2. Cocoa Grow Bull 14:23-27

Are L, Jacob VJ (1971) Rehabilitation of cacao with chupons from coppiced trees. In: Cocoa Producers Alliance (COPAL), 3rd International Cocoa Research Conference, COPAL, Lagos, Nigeria, pp 113-118

Are L, Longworth JF (1965) Partial rehabilitation of various infected cocoa farms. West African Cocoa Researh Institute, Report 1963-1964. WestAfrican Cocoa Researh Institute, Lagos, Nigeria

Are LA (1970b) Rehabilitation of cocoa farms. Cocoa Growers' Bulletin 14:3-27

Armstrong KB (1976) A spacing trial with single and multiple stem cocoa. In: East Malaysia Planters Association, Cocoa-Cocunut Seminar, East Malaysia Planters Association, Sabah, Malaysia, pp 93-104

Asante WA, Acheampong E, Kyereh E, Kyereh B (2017) Farmers' perspectives on climate change manifestations in smallholder cocoa farms and shifts in cropping systems in the forest-savannah transitional zone of Ghana. Land Use Policy 66:374-381. https://doi.org/10.1016/j.landusepol.2017.05.010

Asare R, Afari-Sefa V, Muilerman S (2018) Access to improved hybrid seeds in Ghana: implications for establishment and rehabilitation of cocoa farms. Exp Agr 54(2):273-285. https://doi.org/10.1017/ s0014479716000247

Asare R, David D (2010) Planting replanting and tree diversification in cocoa systems. A guide for participatory farmer training. Development and Environment Series, Manual No 2. Faculty of Life Sciences, University of Copenhagen, Copenhagen, Denmark, $p$ 141

Assiri AA, Deheuvels O, Kebe BI, Petithuguenin P (2003) Techniques paysannes de rehabilitation cacaoyere in Cote de Ivoire. In: Cocoa Producers Alliance (COPAL), 14th International Cocoa Research Conference, COPAL, Lagos, Nigeria, pp 1151-1156
Assiri AA, Kacou EA, Assi FA, Ekra KS, Dji KF, Couloud JY, Yapo AR (2012) Rentabilité économique des techniques de réhabilitation et dereplantation des vieux vergers de cacaoyers (Theobroma cacao L.) en Côte d'Ivoire. J Anim Plant Sci 14(2):1939-1951

Ayanlaja SA (1983) Rehabilitation of cocoa (Theobroma cacao L.) in Nigeria major problems and possible solutions. I. Causes of difficulty of seedling establishment. Plant Soil 73:403-409. https:// doi.org/10.1007/BF02184317

Babin R, ten Hoopen GM, Cilas C, Enjalric F, Yede GP, Lumaret J-P (2010) Impact of shade on the spatial distribution of Sahlbergella singularis in traditional cocoa agroforests. Agric for Entomol 12(1):69-79. https://doi.org/10.1111/j.1461-9563.2009.00453.x

Bastide P, Paulin D, Lachenaud P (2008) Influence de la mortalité des cacaoyers sur la stabilité de la production dans une plantation industrielle. Tropicultura 26(1):33-38

Batista L (2009) Guía Técnica El cultivo de cacao. Centro para el Desarrollo Agropecuario y Forestal, Inc. (CEDAF), Santo Domingo, República Dominicana, pp 87-102

Bertolde FZ, Almeida AAF, Pirovani CP, Gomes FP, Ahnert D, Baligar VC, Valle RR (2012) Physiological and biochemical responses of Theobroma cacao L. genotypes to flooding. Photosynthetica 50(3):447-457. https://doi.org/10.1007/ s11099-012-0052-4

Bleasdale JKA, Nelder JA (1960) Plant population and crop yield. Nature 188:342. https://doi.org/10.1038/188342a0

Blencowe JW, Hubbard TP (1972) Thinning and shaping of denselyplanted cocoa. In: Incorporated Society of Planters, Conference on Cocoa and Coconuts in Malaysia, Kuala Lumpur, Malaysia, pp 86-101

Bunn C, Lundy M, Wiegel J, Castro-Llanos F (2019a) Impacto del cambio climático en la producción de cacao para Centroamérica y el Caribe. Centro Internacional de Agricultura Tropical (CIAT), Cali, Colombia, p 34

Bunn C, Peter L, Quaye A, Sander M, Noponen MRA, Lundy M (2019b) Recommendation domains to scale out climate change adaptation in cocoa production in Ghana. Clim Services 16:100123. https://doi.org/10.1016/j.cliser.2019.100123

Cerda R, Deheuvels O, Calvache D, Niehaus L, Saenz Y, Kent J, Vilchez S, Villota A, Martinez C, Somarriba E (2014) Contribution of cocoa agroforestry systems to family income and domestic consumption: looking toward intensification. Agrofor Syst 88(6):957-981. https://doi.org/10.1007/s10457-014-9691-8

Charles AE (1961) Spacing and shade trials with cacao. PNG Agric J 14(1):1-15

Cilas C, Bastide P (2020) Challenges to cocoa production in the face of climate change and the spread of pests and diseases. Agronomy 10:1232

Clough Y, Dwi Putra D, Pitopang R, Tscharntke T (2009) Local and landscape factors determine functional bird diversity in Indonesian cacao agroforestry. Biol Conserv 142(5):1032-1041. https:// doi.org/10.1016/j.biocon.2008.12.027

Codjoe FNY, Ocansey CK, Boateng DO, Ofori J (2013) Climate change awareness and coping strategies of cocoa farmers in rural Ghana. J Biol Agric Healthc 3(11):19-29

Cuello J, Morales ME, Rib S (2015) National cocoa action plan for sustainable development. Ministerio de Agricultura, Comisión Nacional del Cacao.Santo Domingo, Republica Dominicana, $p$ 46

Dalberg (2015) Smallholder tree crop renovation and rehabilitation (R\&R). A review of the State of the emerging R\&R market and opportunities to scale investment. idh the sustainable trade initiative. IDH The Sustainable Trade Initiative, Utrecht, The Netherlands, p 78

Danquah FK (2003) Sustaining a West African cocoa economy agricultural science and the swollen shoot contagion in Ghana, 19361965. Afr Econ Hist 31:43-74 
De Pinto A, Robertson R, D., Obiri BD, (2013) Adoption of climate change mitigation practices by risk-averse farmers in the Ashanti Region, Ghana. Ecol Econ 86:47-54. https://doi.org/10.1016/j. ecolecon.2012.11.002

de Sousa K, van Zonneveld M, Holmgren M, Kindt R, Ordoñez JC (2019) The future of coffee and cocoa agroforestry in a warmer Mesoamerica. Scientfic Reports 9:8828. https://doi.org/10.1038/ s41598-019-45491-7

Denkyirah EK, Okoffo ED, Adu DT, Bosompem OA, Yildiz F (2017) What are the drivers of cocoa farmers' choice of climate change adaptation strategies in Ghana? Cogent Food Agric 3(1). https:// doi.org/10.1080/23311932.2017.1334296

Dias L, Santos M, Santos A, Almeida C, Cruz C, Carneiro P (2000) Effect of planting density on yield and incidence of witches' broom disease in a young plantation of hybrid cacao trees. Exp Agr 36:501-508. https://doi.org/10.1017/S001447970000106X

Dias L, Souza C, Augusto S, SIqueira PR, Muller MW, (2003) Periodo mínimo de colheita para la avaliacao de cultivares de cacau en Linhares, ES. Rev Arvore 27:495-501. https://doi.org/10.1590/ S0100-67622003000400010

Dzahini-Obiatey H, Ameyaw GA, Ollennu LA (2006) Control of cocoa swollen shoot disease by eradicating infected trees in Ghana: a survey of treated and replanted areas. Crop Protect 25(7):647652. https://doi.org/10.1016/j.cropro.2005.09.004

Dzahini-Obiatey HK, Domfeh O, Amoah FM (2010) Over seventy years of a viral disease of cocoa in Ghana: from researchers' perspective. Afr J Agric Res 5(7):476-485. https://doi.org/10. 5897/AJAR09.625

Egbe NE, Adenikinju SA (1990) Effect of intercropping on potential yield of cacao in South Western Nigeria. Cafe Cacao the 34(4):281-284

Enríquez GA, Paredes LF (1981) Establecimiento de 6 hibridos de cacao por el metodo de renovación Turrialba. In: Cocoa Producers Alliance (COPAL), 8va Conferencia Internacional de Investigación en Cacao, COPAL, Lagos, Nigeria, pp 9-13

Freeman WG (1929) Results of cacao research at River Estate. Trinidad Trop Agric 6(5):127-133

Frimpong EB, Adu-Ampomah Y, Dwapanyin AO, Abdul-Karimu A (2003) Efforts to re-establish cocoa in denuded cocoa growing areas of Ghana. In: Cocoa Producers Alliance (COPAL), 14th International Cocoa Research Conference, COPAL, Lagos, Nigeria, pp 317-324

Gateau-Rey L, Tanner EVJ, Rapidel B, Marelli JP, Royaert S (2018) Climate change could threaten cocoa production: effects of 2015-16 El Nino-related drought on cocoa agroforests in Bahia. Brazil Plos One 13:e0200454. https://doi.org/10.1371/journal. pone. 0200454

Gidoin C, Babin R, Bagny Beilhe L, Cilas C, ten Hoopen GM, Bieng MA (2014) Tree spatial structure, host composition and resource availability influence mirid density or black pod prevalence in cacao agroforests in Cameroon. PLoS ONE 9:e109405. https:// doi.org/10.1371/journal.pone.0109405

Gotsch N, Burger K (2001) Dynamic supply response and welfare effects of technological change on perennial crops: the case of cocoa in Malaysia. Am J Agric Econ 83(2):272-285

Granados Ramírez GR, Pérez Sosa E (2020) Posibles efectos del cambio climático en la región productora de cacao en Tabasco, México. Tlalli Rev Invest Geogr 3:39-67. https://doi.org/10.22201/ ffyl.26832275e.2020.3.1069

Grisales A, Cubillos G (1985) Rehabilitación de poblaciones de cacao deterioradas por escoba de bruja mediante el metodo de renovacion de copa. El Cacaotero Colomb 31:36-41

Guharay F, Monterroso D, Staver C (2001) El diseño y manejo de la sombra para la supresión de plagas en cafetales de América Central. Agrofor Am 8(29):22-29
Gusli S, Sumeni S, Sabodin R, Muqfi IH, Nur M, Hairiah K, Useng D, van Noordwijk M (2020) Soil organic matter, mitigation of and adaptation to climate change in cocoa-based agroforestry systems. Land 9(323). https://doi.org/10.3390/land9090323

Jacobi J, Schneider M, Bottazzi P, Pillco M, Calizaya P, Rist S (2013) Agroecosystem resilience and farmers' perceptions of climate change impacts on cocoa farms in Alto Beni. Bolivia Renew Agric Food Syst 30(2):170-183. https://doi.org/10.1017/s1742 $17051300029 \mathrm{x}$

Jagoret P, Kwesseu J, Messie C, Michel-Dounias I, Malézieux E (2014) Farmers' assessment of the use value of agrobiodiversity in complex cocoa agroforestry systems in central Cameroon. Agrofor Syst 88(6):983-1000. https://doi.org/10.1007/ s10457-014-9698-1

Jagoret P, Michel-Dounias I, Malézieux E (2011) Long-term dynamics of cocoa agroforests: a case study in central Cameroon. Agrofor Syst 81(3):267-278. https://doi.org/10.1007/s10457-010-9368-x

Jagoret P, Michel-Dounias I, Snoeck D, Ngnogué HT, Malézieux E (2012) Afforestation of savannah with cocoa agroforestry systems: a small-farmer innovation in central Cameroon. Agrofor Syst 86(3):493-504. https://doi.org/10.1007/s10457-012-9513-9

Jagoret P, Michel I, Ngnogué HT, Lachenaud P, Snoeck D, Malézieux E (2017a) Structural characteristics determine productivity in complex cocoa agroforestry systems. Agron Sustain Dev 37(6). https://doi.org/10.1007/s13593-017-0468-0

Jagoret P, Ngnogue HT, Malézieux E, Michel I (2018) Trajectories of cocoa agroforests and their drivers over time: lessons from the Cameroonian experience. Eur J Agron 101:183-192. https://doi. org/10.1016/j.eja.2018.09.007

Jagoret P, Snoeck D, Bouambi E, Ngnogue HT, Nyassé S, Saj S (2017b) Rehabilitation practices that shape cocoa agroforestry systems in Central Cameroon: key management strategies for long-term exploitation. Agrofor Syst 92(5):1185-1199. https:// doi.org/10.1007/s10457-016-0055-4

Kieck JS, Zug KLM, Huamaní Yupanqui HA, Gómez Aliaga R, Cierjacks A (2016) Plant diversity effects on crop yield, pathogen incidence, and secondary metabolism on cacao farms in Peruvian Amazonia. Agric, Ecosyst Environ 222:223-234. https://doi.org/ 10.1016/j.agee.2016.02.006

Kowal JML (1959) The effect of spacing on the environment and performance of cacao under Nigerian conditions. Empire J Exp Agr 27(106): 138-149

Krauss U, Soberanis W (2002) Effect of fertilization and biocontrol application frequency on cocoa pod diseases. Biol Control 24(1):82-89. https://doi.org/10.1016/S1049-9644(02)00007-5

Kroeger A, Koenig S, Thomson A, Streck C, Weiner PH, Bakhtary H (2017) Forest and climate-smart cocoa in Côte d'Ivoire and Ghana, aligning stakeholders to support smallholders in deforestation-free cocoa. The World Bank, Washington, DC, USA

Kwaw-Nimeson E, Tian Z (2019) Impact assessment of the cocoa rehabilitation project on cocoa exports in Ghana. Open J Soc Sci 07(09):207-219. https://doi.org/10.4236/jss.2019.79015

Lachenaud P (2003) Densite evolutive en cacaoculture la necessite des eclaircies.In: Cocoa Producers Alliance (COPAL), 14th International Cocoa Research Conference, COPAL, Lagos, Nigeria, pp 310-316

Läderach P, Martinez-Valle A, Schroth G, Castro N (2013) Predicting the future climatic suitability for cocoa farming of the world's leading producer countries, Ghana and Côte d'Ivoire. Clim Change 119:841-854. https://doi.org/10.1007/ s10584-013-0774-8

Läderach P, Ramirez-Villegas J, Navarro-Racines C, Zelaya C, Martinez-Valle A, Jarvis A (2017) Climate change adaptation of coffee production in space and time. Clim Change 141(1):47-62. https://doi.org/10.1007/s10584-016-1788-9 
Lahive F, Hadley P, Daymond AJ (2018) The physiological responses of cacao to the environment and the implications for climate change resilience. A review. Agron Sustain Dev 39(1). https:// doi.org/10.1007/s13593-018-0552-0

Laryea AA (1969) Cocoa rehabilitation in Ghana. In: Cocoa Producers Alliance (COPAL), 3rd. International Cocoa Research Conference, COPAL, Lagos, Nigeria, pp 37-48

Lass RA (1985) Replanting and rehabilitation of old cocoa farms. In: Wood GAR, Lass RA (eds) Cocoa. Longman, Harlow, UK, pp 210-233

Leandro-Muñoz ME, Tixier P, Germon A, Rakotobe V, Phillips-Mora W, Maximova S, Avelino J (2017) Effects of microclimatic variables on the symptoms and signs onset of Moniliophthora roreri, causal agent of Moniliophthora pod rot in cacao. PLoS ONE 12:e184638. https://doi.org/10.1371/journal.pone.0184638

Lockwood G (1976) A comparison of the growth and yield during a 20 year period of Amelonado and Upper Amazon hybrid cocoa in Ghana. Euphytica 25:647-658. https://doi.org/10.1007/BF000 41602

Lockwood G, Yin JP (1996) Yields of cocoa clones in response to planting density in Malaysia. Exp Agr 32:41-47. https://doi.org/ $10.1017 / \mathrm{S} 0014479700025837$

Longworth JF (1963) The effect of swollen shoot disease on mature cocoa in Nigeria. Trop Agric 40:275-283

Mahrizal NLL, Dixon BL, Popp JS (2014) An optimal phased replanting approach for cocoa trees with application to Ghana. Agric Econ 45(3):291-302. https://doi.org/10.1111/agec.12065

Malézieux E (2012) Designing cropping systems from nature. Agron Sustain Dev 32:15-29. https://doi.org/10.1007/ s13593-011-0027-z

Martin E (1957) Preliminary studies in replanting cacao in Costa Rica. Thesis Magister Agriculturae, InterAmerican Institute of Agricultural Sciences (IICA), Turrialba, Costa Rica, p 90

Matlick BK, Purdy LH, Stevenson C (1999) Technical support to Haitian cacao. South East Consortium for International Development (SECID)/Auburn University, PLUS Report No. 48.Auburn, Alabama, USA, p 40

Mead R (1970) Plant density and crop yield. Appl Statist 19:64-81. https://doi.org/10.2307/2346843

Melendez L (1991) Sombras temporales para cacao. In: Phillips W (ed) Sombras y cultivos asociados con cacao. Serie Técnica Informe Técnico 206, CATIE, Turrialba, Costa Rica, pp 99-110

Middendorp RS, Vanacker V, Lambin EF (2018) Impacts of shaded agroforestry management on carbon sequestration, biodiversity and farmers income in cocoa production landscapes. Landscape Ecol 33(11):1953-1974. https://doi.org/10.1007/ s10980-018-0714-0

Montgomery P (1981) Some thoughts on the life span of cocoa. Planter 57:604-609

Mooleedhar V, Lauckner F (1990) Effects of spacing on yield in improved clones of Theobroma cacao L. Trop Agric (trinidad) 67(4):376-378

Murray DB, Jones MR (1969) The impact of cocoa rehabilitation schemes in Trinidad and Grenada. In: Cocoa Producers Alliance (COPAL), 3rd International Cocoa Research Conference, COPAL, Lagos, Nigeria, pp 133-137

Obiri BD, Bright GA, McDonald MA, Anglaaere LCN, Cobbina J (2007) Financial analysis of shaded cocoa in Ghana. Agrofor Syst 71(2):139-149. https://doi.org/10.1007/s10457-007-9058-5

Ofori-Bah A, Asafu-Adjaye J (2011) Scope economies and technical efficiency of cocoa agroforesty systems in Ghana. Ecol Econ 70(8):1508-1518. https://doi.org/10.1016/j.ecolecon.2011.03. 013

Ogunniyi G, Osuolale TO (2015) Tenure implication and property right on adoption of cocoa rehabilitation techniques in Osun State of
Nigeria. Afr J Agric Res 3(4):230-236. https://doi.org/10.26524/ jms.2015.6

Oladokun MAO (1990) Tree crop based agroforestry in Nigeria: a checklist of crops intercropped with cocoa. Agrofor Syst 11:227241. https://doi.org/10.1007/BF00045901

Olaiya AO, Fagbayide JA, Hammed LA, Aliyu MO (2006) Comparison of potential pod yield and loss in old and rehabilitated cocoa plots. Afr J Agric Res 1(5):189-193

Oluwatusin FM (2014) The perception of and adaptation to climate change among cocoa farm households in Ondo State. Nigeria Acad J Interdiscip Stud 3(1):147-156. https://doi.org/10.5901/ ajis.2014.v3n1p147

Orozco-Aguilar L, Deheuvels O, VIllalobos M, Somarriba E (2015) El sector cacao en Centroamerica: Estado de desarrollo en el año 2007. Serie Técnica, Informe Técnico 401, CATIE, Turrialba, Costa Rica, p 86

Oyekale A, Adepoju A (2012) Determinants of agricultural intensification in Southwest Nigeria. Life Sci J 9(3):370-376

Pacheco RG, Aguilar M, Gomes A, Marrocos PCL, Sodré GA, Chepotte RE, Pereira AB (2003) Efeito de espacamento na producao e estado fitossanitario do cacaueiro sob cobertura de pupunha na regiao cacaaueria da Bahia. In: Cocoa Producers Alliance (COPAL), 14th International Cocoa Research Conference, COPAL, Lagos, Nigeria, pp 469-472

Padi FK, Adu-Gyamfi P, Akpertey A, Arthur A, Ofori A (2013) Differential response of cocoa (Theobroma cacao) families to field establishment stress. Plant Breed 132(2):229-236. https://doi. org/10.1111/pbr.12039

Panik MJ (2013) Growth curve modeling: theory and applications. Chapter 7. Yield-density curves. Wiley, New York

Pekic V (2014) Uncertain future for Brazilian cocoa production. William Reed Business Media Ltd 2021. https://www.confection erynews.com/article/2014/10/13/brazil-s-cocoa-production-tofall-next-decade. Accessed 12/10/2020 2020

Petithughenin P (1995) Regeneration of cocoa cropping systems: the Ivoria and Togolese experiences. In: Ruf FO, Siswoputrano PS (eds) Cocoa cycles: the economics of cocoa supply. Woodhead Publishing Limited, Cambridge, England, pp 89-106

Poelmans E, Swinnen J (2016) A brief economic history of chocolate. In: Squicciarini MP, Swinnen J (eds) The economics of chocolate. Oxford University Press, Oxford, England, pp 11-42

Quiroz V, Amores F (2002) Rehabilitación de plantaciones tradicionales de cacao en Ecuador. Manejo Integr Plagas (costa Rica) 63:73-80

Read D (2019) Climate smart chocolate. In: Climate smart food. Palgrave Pivot, Cham, Switzerland, pp 69-79. https://doi.org/10. 1007/978-3-030-18206-9_6

Riedel J, Kägi N, Armengot L, Schneider M (2019) Effects of rehabilitation pruning and agroforestry on cacao tree development and yield in an older full-sun plantation. Exp Agr:1-17. https://doi. org/10.1017/s0014479718000431

Ruf F, Zadi H (1998) Cocoa: from deforestation to reforestation. Smithsonian Institute Migratory Bird Center, 1st. International workshop on sustainable cocoa growing. Smithsonian Institution, Panama City, Panama, p 36. http://nationalzoo.si.edu/conservati onandscience/migratorybirds/research/cacao/ruf.cfm. Accessed 17 Aug 2021

Ruf FO (2011) The Myth of complex cocoa agroforests: the case of Ghana. Hum Ecol 39:373-388. https://doi.org/10.1007/ s10745-011-9392-0

Ryan D, Bright GA, Somarriba E (2009) Damage and yield change in cocoa crops due to harvesting of timber shade trees in Talamanca. Costa Rica Agrofor Syst 77(2):97-106. https://doi.org/ 10.1007/s10457-009-9222-1

Saj S, Jagoret P, Etoa LE, Eteckji Fonkeng E, Tarla JN, Essobo Nieboukaho J-D, Mvondo Sakouma K (2017) Lessons learned from 
the long-term analysis of cacao yield and stand structure in central Cameroonian agroforestry systems. Agric Syst 156:95-104. https://doi.org/10.1016/j.agsy.2017.06.002

Saj S, Jagoret P, Todem Ngogue H (2013) Carbon storage and density dynamics of associated trees in three contrasting Theobroma cacao agroforests of Central Cameroon. Agrofor Syst 87(6):1309-1320. https://doi.org/10.1007/s10457-013-9639-4

Schroth G, Garcia E, Griscom BW, Teixeira WG, Barros LP (2015a) Commodity production as restoration driver in the Brazilian Amazon? Pasture re-agro-forestation with cocoa (Theobroma cacao) in southern Pará. Sustain Sci 11(2):277-293. https://doi. org/10.1007/s11625-015-0330-8

Schroth G, Garcia E, Griscom BW, Teixeira WG, Barros LP (2016a) Commodity production as restoration drive in the Brazilian Amazon? Pasture re-agro-forestation with cocoa (Theobroma cacao) in southern Pará. Sustain Sci 11(2):277-293. https://doi.org/10. 1007/s11625-015-0330-8

Schroth G, Läderach P, Blackburn Cuero DS, Neilson J, Bunn C (2015b) Winner or loser of climate change? A modeling study of current and future climatic suitability of Arabica coffee in Indonesia. Reg Environ Change 15(7):1473-1482. https://doi. org/10.1007/s10113-014-0713-X

Schroth G, Laderach P, Martinez-Valle AI, Bunn C, Jassogne L (2016b) Vulnerability to climate change of cocoa in West Africa: patterns, opportunities and limits to adaptation. Sci Total Environ 556:231-241. https://doi.org/10.1016/j.scitotenv.2016.03.024

Scott G, Donovan J, Higuchi A (2015) Costs, quality, and competition in the cocoa value chain in Peru: an exploratory assessment. Custos e Agronegocio 11(4):324-358

Siegel P, Alwang J (2004) Export commodity production and broadbased rural development: coffee and cocoa in the Dominican Republic. Policy Research Working Paper; No.3306. The World Bank, Washington, D.C. https://doi.org/10.1596/1813-9450-3306

Smiley GL, Kroschel J (2009) Yield development and nutrient dynamics in cocoa-gliricidia agroforests of Central Sulawesi. Indonesia Agrofor Syst 78(2):97-114. https://doi.org/10.1007/ s10457-009-9259-1

Smith RW (2015) The spacing of West African Amelonado cocoa in Ghana. J Hortic Sci 35(3):176-184. https://doi.org/10.1080/ 00221589.1960 .11513982

Somarriba E, Cerda R, Orozco L, Cifuentes M, Dávila H, Espin T, Mavisoy H, Ávila G, Alvarado E, Poveda V, Astorga C, Say E, Deheuvels O (2013) Carbon stocks and cocoa yields in agroforestry systems of Central America. Agric, Ecosyst Environ 173:46-57. https://doi.org/10.1016/j.agee.2013.04.013

Somarriba E, Lachenaud P (2013) Successional cocoa agroforests of the Amazon-Orinoco-Guiana shield. For, Trees Livelihoods 22(1):51-59. https://doi.org/10.1080/14728028.2013.770316

Somarriba E, López-Sampson A (2018) Coffee and cocoa agroforestry systems: pathways to deforestation, reforestation, and tree cover change. Leaves. The World Bank, Washington

Somarriba E, Orozco-Aguilar L, Cerda R, López-Sampson A (2018) Analysis and design of the shade canopy of cocoa-based agroforestry systems. In: Umaharan P (ed) Achieving sustainable cultivation of cocoa. Burleigh Dodds Science Publishing, Cambridge, UK, pp 469-500. https://doi.org/10.19103/as.2017.0021.29

Somarriba E, Suárez-Islas A, Calero-Borge W, Villota A, Castillo C, Vílchez S, Deheuvels O, Cerda R (2014) Cocoa-timber agroforestry systems: Theobroma cacao-Cordia alliodora in Central America. Agrofor Syst 88(6):1001-1019. https://doi.org/10. 1007/s10457-014-9692-7

Somarriba E, Zamora R, González J, Malek M, Vargas E, Sinclair F, Quesada F (2020) ShadeMotion: el análisis de patrones de sombra de árboles. Tutorial CATIE, Serie técnica. Manual técnico 145. CATIE, Turrialba, Costa Rica
Soria J, Garcia JR (1968) Metodo de renovacao sob plantios velhos de cacau. Cacau Atual 5:5-8

Spaggiari Souza S, Dias L, Galeas Aguilar M, Sonegheti S, Oliveira J, Andrade Costa J (2009) Cacao yield in different planting densities. Braz Arch Biol Techn 52(6):1313-1320. https://doi.org/10. 1590/S1516-89132009000600001

Teixeira P, Thomazella D, Pereira G (2015) Time for chocolate: current understanding and new perspectives on cacao witches' broom disease research. PLoS Pathogen 11(10):e1005130. https://doi. org/10.1371/journal.ppat.1005130

Thau Yin JP (2004) Rootstock effects on cocoa in Sabah. Malaysia Exp Agr 40(4):445-452. https://doi.org/10.1017/s0014479704002108

Tresh JA, Lister RM (1960) Coppicing experiments on the spread and control of cacao swollen shoot disease in Nigeria. Ann Appl Biol 48(1):65-74

Trivedi PK (1988) A model of cocoa replanting and new planting in bahia brazil 1966-1985. International Economics Department. The World Bank, Washington, DC

Tscharntke T, Clough Y, Bhagwat SA, Buchori D, Faust H, Hertel D, Hölscher D, Juhrbandt J, Kessler M, Perfecto I, Scherber C, Schroth G, Veldkamp E, Wanger TC (2011) Multifunctional shade-tree management in tropical agroforestry landscapes - a review. J Appl Ecol 48(3):619-629. https://doi.org/10.1111/j. 1365-2664.2010.01939.x

Upton M (1966) Tree crops: a long term investment. J Agric Econ 17(1):92-90. https://doi.org/10.1111/j.1477-9552.1966.tb019 82.x

Urquhart DH (1961) Cocoa. 2nd edn. Longmans, Green and Co, London

Vaast P, Somarriba E (2014) Trade-offs between crop intensification and ecosystem services: the role of agroforestry in cocoa cultivation. Agrofor Syst 88(6):947-956. https://doi.org/10.1007/ s10457-014-9762-x

van der Kooij S (2013) Market study of fine flavour cocoa in 11 selected countries. Royal Tropical Institute, KIT Development Policy \& Practice, Amsterdam, The Netherlands, p 109

Vandermeer J (1984) Plant competition and the yield-density relationship. J Theor Biol 109(3):393-399. https://doi.org/10.1016/ s0022-5193(84)80088-0

Vanhove W, Vanhoudt N, Van Damme P (2016) Effect of shade tree planting and soil management on rehabilitation success of a 22-year-old degraded cocoa (Theobroma cacao L.) plantation. Agric, Ecosyst Environ 219:14-25. https://doi.org/10.1016/j. agee.2015.12.005

Vaz A (1995) Rehabilitacion de cacaotales, conceptos basicos. Módulo de capacitacion para productores, CATIE, Turrialba, Costa Rica, p 36

Vello F, Garcia JR, Magalhaes WS (1971) Renovacao de cacaueiros velhos na Bahia. In: 3rd International Cocoa Research Conference, COPAL, Lagos, Nigeria, pp 123-132

Vernon AJ (1971) Cocoa spacing, pruning, and random death. In: Cocoa Producers Alliance (COPAL), 3rd International Cocoa Research Conference, COPAL, Lagos, Nigeria, pp 338-345

Vernon AJ, Morris MG (2015) Variability in West African peasant cocoa farms; time studies on Agodi cocoa yields. J Hortic Sci 39(4):241-253. https://doi.org/10.1080/00221589.1964.11514 108

Vigneri M (2007) Drivers of cocoa production growth in Ghana. Overseas Development Institute (ODI), Project Briefing \#4. Overseas Development Institution, London, UK, p 4

Wessel M (1969) Soil aspects of cacao rehabilitation in Western Nigeria. In: Cocoa Producers Alliance (COPAL), 3rd International Cocoa Research Conference, COPAL, Lagos, Nigeria, pp 81-85

Wessel M, Quist-Wessel PMF (2015) Cocoa production in West Africa, a review and analysis of recent developments. NJAS-Wag J Life Sci 74-75:1-7. https://doi.org/10.1016/j.njas.2015.09.001 
Willey RM, Heath SB (1969) The quantitative relationship between plant population and crop yield. Adv Agron 21:281-321. https:// doi.org/10.1016/S0065-2113(08)60100-5

Wood GAR (1964) Spacing Cocoa Grow Bull 2:16-18

Yahuza I (2011) Yield-density equations and their application for agronomic research: a review. Int J Biosci 1(5):1-17
Publisher's note Springer Nature remains neutral with regard to jurisdictional claims in published maps and institutional affiliations. 